Summary Appraisals of the

Nation's Ground-Water Resources-

Upper Mississippi Region

GEOLOGICAL SURVEY PROFESSIONAL PAPER 813-B

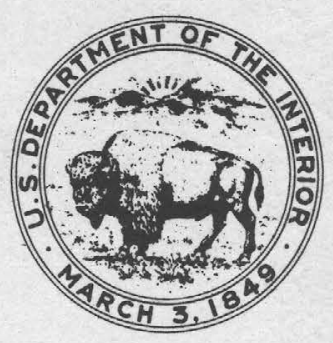





\section{Summary Appraisals of the}

Nation's Ground-Water ResourcesUpper Mississippi Region

By R. M. BLOYD, JR.

GEOLOGICAL S URVEY PROFESSIONAL PAPER 813-B

Ground-water development and management opportunities in

the region

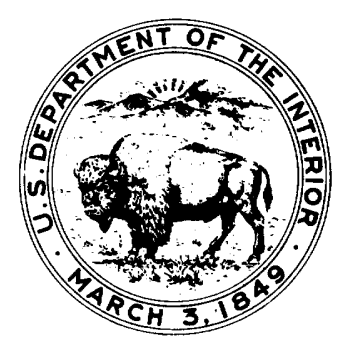




\section{UNITED STATES DEPARTMENT OF THE INTERIOR}

\section{GEOLOGICAL SURVEY}

V. E. McKelvey, Director

First printing 1975

Second printing 1978

Library of Congress Cataloging in Publication Data

Bloyd, R. M.

Summary appraisals of the nation's ground-water resources, Upper Mississippi, region.

(Geological Survey Professional Paper 813-B)

Bibliography: p. 22

Supt. of Docs. No.: I 19.16:813-B

1. Water-supply-Mississippi Valley. 2. Water, Underground-Mississippi Valley. I. Title. II. Series: United States. Geological Survey. Professional Paper 813-B.

TD225.M64B58

333.9'104'0977

$75-619085$

For sale by the Superintendent of Documents, U.S. Government Printing Office

Washington, D.C. 20402

Stock Number 024-001-02688-1 


\section{CONTENTS}

Abstract

Introduction

Integrating ground water into water-resource planning

Technology available for planning

Data requirements for planning

Assessing the ground-water resource

Geologic framework

Precipitation-the source

Evapotranspiration-a major use

The supply

Potable water

Saline water

Defining movement of water through the system _..._._. 11

Stream-aquifer interrelation

Ground-water recharge _..._._._._._._._._._. 13

Productivity of aquifers in the Upper Mississippi Region- 13

Water-supply needs

Current _...

Projected _...
Page

The significance of the subsurface system in the Upper Mississippi Region _._._. B16

The potential for additional development $\ldots \ldots \ldots$

Ground water to satisfy local water requirements _...... 17

Ground water as a regional resource _............ 17

The potential for underground waste disposal _..._._. 18

Water-management implications of the hydrologic analysis _- 19

Some concepts related to water management _._._._._._. 19

Principle of continuity _._. 19

Yield of the system .......... 19

Conservation of ground water ................ 19

Advantages (for management) of the subsurface system _. 19

Water-management alternatives _.................. 21

Increase inflow to the hydrologic system _......... 21

Salvage outflow from the hydrologic system _._... 21

Use of artificial recharge to maintain balance between inflow and outflow

Summary .............. 21

Selected references ............ 22

\section{ILLUSTRATIONS}

FIgure 1. Map showing subbasins in the Upper Mississippi Region described in this report

2. Map showing distribution of outwash and alluvial deposits

3. Map showing major geologic subdivisions of the bedrock in the Upper Mississippi Region

4. Map showing average annual precipitation

5. Map showing estimated average annual potential evapotranspiration

6. Graph showing the liquid- and vapor-discharge components and their relation to total ground-water discharge

7. Map showing high-yield sources of ground water

8. Map showing low-yield sources of ground water

\section{TABLES}

TABLE 1. Year 1960 and projected municipal and industrial water use-Upper Mississippi Region

2. Potential water-supply problem areas _...

3. Estimated average annual subbasin precipitation

4. Calculation of water in storage in the outwash and alluvial aquifers of the subbasins

5. Summary of ground-water recharge computations _

6. Base year (1960) domestic, commercial, and rural ground-water use

7. Estimated total municipal and industrial water use for the year 2020

8. Comparison of ground-water withdrawals with estimated ground-water recharge

9. Estimated irrigation-water requirements for the year 2020 



\title{
SUMMARY APPRAISALS OF THE NATION'S GROUND-WATER RESOURCES-UPPER MISSISSIPPI REGION
}

\author{
By R. M. BLOYD, JR.
}

\section{ABSTRACT}

The Upper Mississippi Region in general is rich in water-surface water is plentiful, and ground water is a large, important, and manageable resource. Total potable water in storage in the outwash and alluvial aquifers of the Mississippi River valley and the subbasins is about 45,000 billion gallons. This is about 10 percent of the water in storage in Lake Ontario. Water in storage in other aquifers of the region is probably at least several times that in the outwash and alluvial aquifers. Estimated ground-water recharge in the subbasins is 23,000 million gallons per day.

A comparison of ground-water withdrawals with estimated ground-water recharge suggests that the large ground-water resource of the region is not being fully utilized. Ground-water use by domestic, commercial, and rural interests is only 4 percent of recharge. Ground-water use (1965) by industry is only 3 percent of recharge.

Water in the outwash and alluvial aquifers of much of the valley of the Mississippi River in and south of St. Paul, Minn. of the Illinois River, the Lower Minnesota River, the Wisconsin River, the Lower Black River, the Wapsipinicon River, the Lower Rock River, and the Upper Des Moines River can be considered a regional resource. In these areas the ground-water resources are of sufficient magnitude to satisfy more than just local needs. For cxample, under certain specified conditions, ground water in the above areas can supply approximately 20 million additional people. Factors other than water supply, of course, will be constraints on development in the region.

Advances in techniques in ground-water hydrology during recent years have provided methods that the hydrologist and planner can use for planning and design of ground-water developments. Therefore, the planner can now resolve some of the development and management questions that historically have bred uncertainty when this part of the water resource was considered for development.

\section{INTRODUCTION}

This report emphasizes the role of ground water in water-resource planning for a region of expanding development and changing economic environment. The boundaries of the study area are the surface-water drainage boundaries of the Mississippi River basin above the mouth of the Ohio River, exclusive of the Missouri River drainage. For purposes of analysis, the area is divided into 16 subbasins (fig. 1). The subbasin boundaries coincide with the boundaries established in the Upper Mississippi River comprehensive basin study (U.S. Army Corps of Engineers, 1970a, Appendices A-P.)
According to projections in the Upper Mississippi River comprehensive basin study, increasing urbanization, with an attendant decline in agricultural employment, will characterize the future economy of the region. Such a development pattern is not unique to this region-the relative importance of farm-labor employment in crop production has declined and continues to decline in much of the United States.

Increasing urbanization will result in a greater population being served by municipal water-supply systems and waste-treatment facilities. Total regional municipal and industrial water requirements are expected to increase 4.7 times from 1960 to 2020 (table 1). The most rapidly growing economic subregion, historically and projected, is the Milwaukee subregion, Wis. (U.S. Army Corps of Engineers, 1970c, Appendix P, p. P-10), which includes the Madison and Milwaukee areas (U.S. Army Corps of Engineers, 1970, Appendix P, p. P-74). Other rapidly growing economic subregions are Minneapolis-St. Paul, Chicago, Davenport-Rock Island-Moline, Peoria, Des Moines-Fort Dodge, and St. Louis.

Fortunately, the region is rich in water, so that the increasing water demands are not cause for alarm. These rising demands do, however, signal the need for planned and orderly development of the region's water. Currently, water supplies are sufficient for municipal and industrial water needs throughout the region, with few exceptions (U.S. Dept. of the Interior, FWQA, 1970, Appendix H, p. H-31). With increasing water demands, analysis of supply and demand data suggests 26 watersupply problem areas in the region (U.S. Dept. of the Interior, FWQA, 1970, Appendix H, p. H-321-H-331) by the year 2020 (table 2 ). Water-supply problem areas are those where evaluation of local water resources indicates that the resource is insufficient in relation to anticipated water demands. Water quality, too, is a consideration in the identification of problem areas.

Because the region is rich in water, programs of action, ideally, would utilize that richness in the most effective manner. In order to determine what those 


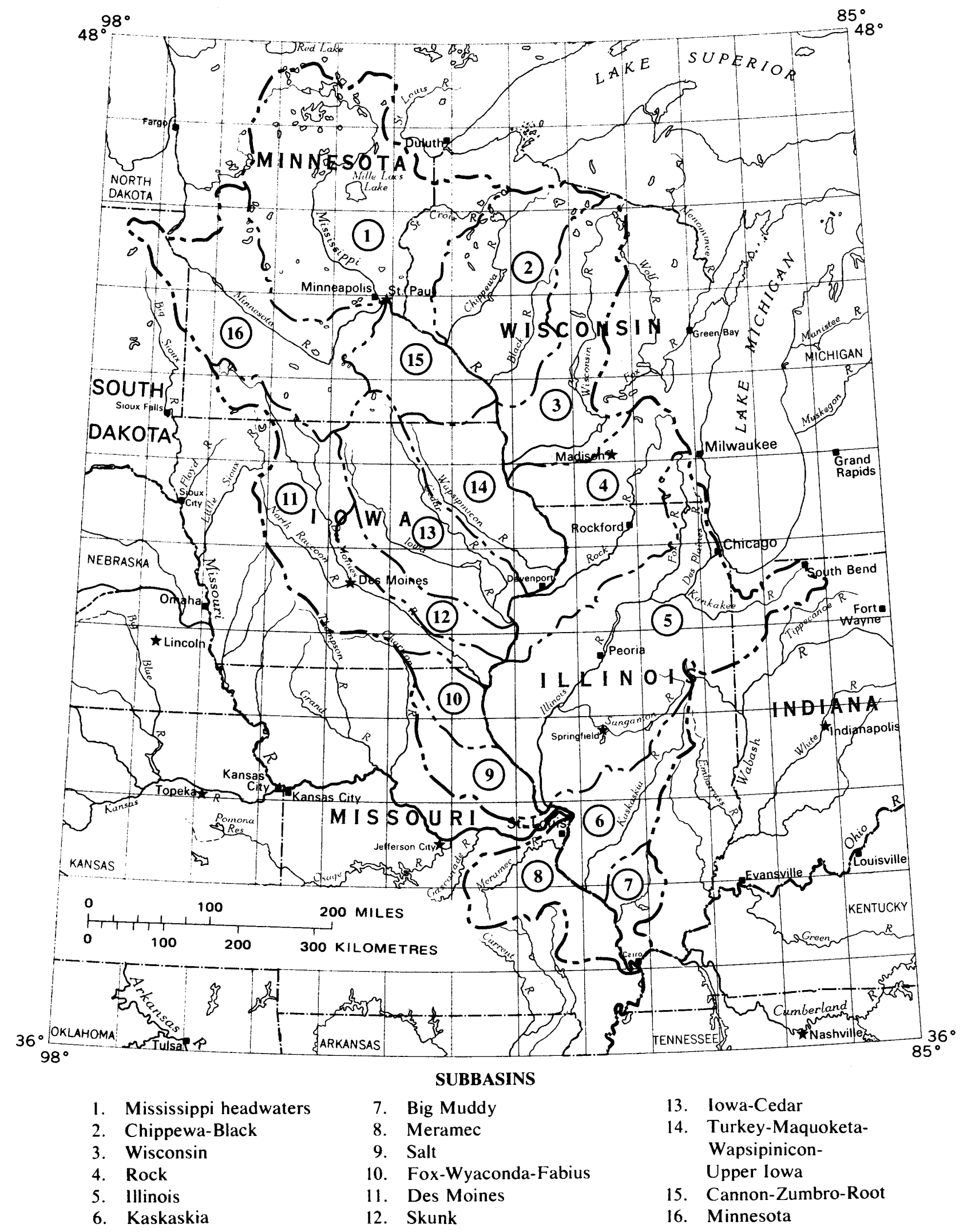

Figure 1.-Subbasins in the Upper Mississippi Region described in this report. 
TABLE 1.-Year 1960 and projected municipal and industrial water use-Upper Mississippi Region

[Table after U.S. Dept. of the Interior, FWQA, 1970, Appendıx H, Table H-9. Units in million gallons per day]

\begin{tabular}{|c|c|c|c|c|}
\hline \multirow[b]{2}{*}{ Subbasin } & \multicolumn{4}{|c|}{ Water use } \\
\hline & 1960 & 1980 & 2000 & 2020 \\
\hline Mississippi headwaters & 291 & 501 & 717 & 1,054 \\
\hline Chippewa-Black & 51 & 95 & 151 & 220 \\
\hline Wisconsin & 196 & 340 & 582 & 946 \\
\hline Rock & 236 & 432 & 736 & 1,208 \\
\hline Illinois & 2,850 & 4,727 & 7,887 & 12,297 \\
\hline Kaskaskia -- & 235 & 377 & 758 & 1,318 \\
\hline Big Muddy & 19 & 28 & 41 & 51 \\
\hline Meramec & 260 & $5 \overline{77}$ & 991 & 1,959 \\
\hline Salt & 12 & 24 & 46 & 89 \\
\hline Fox-Wyaconda-Fabius & 11 & 19 & 33 & 53 \\
\hline Des Moines & 133 & 234 & 405 & 657 \\
\hline Skunk $\ldots$ & 25 & 48 & 85 & 143 \\
\hline Iowa-Cedar & 152 & 273 & 498 & 800 \\
\hline Turkey-Maquoketa-Upper & & & & \\
\hline Iowa-Wapsipinicon & 121 & 217 & 372 & 622 \\
\hline Cannon-Zumbro-Root & 45 & 91 & 174 & 327 \\
\hline Minnesota & 50 & 99 & 180 & 328 \\
\hline Total & 4,687 & 8,082 & 13,656 & 22,072 \\
\hline
\end{tabular}

programs would be, knowledge of the effects of man's activities on the hydrologic system in the region is necessary. Regardless of the plan of action chosen, development will alter the pattern of movement and discharge of water.

In this report, figures for measures are given in English units. The following table contains the factors for converting these English units to metric units:

\begin{tabular}{|c|c|c|c|c|}
\hline English unit & Symbol & $\begin{array}{c}\text { Equivalent } \\
\text { (multiply by) }\end{array}$ & Metric unit & Symbol \\
\hline Inches & (in) & 25.4 & Milimetres & $(\mathrm{mm})$ \\
\hline .... & (ft) & 0.3048 & Metres & (m) \\
\hline Miles _. & (mi) & 1.609 & Kilometres & $(\mathrm{km})$ \\
\hline Acres ...... & & 0.4747 & Hectares & (ha) \\
\hline Square miles & $\left(\mathrm{mi}^{2}\right)$ & 2.590 & $\begin{array}{l}\text { Square } \\
\text { kilometres }\end{array}$ & $\left(\mathrm{km}^{2}\right)$ \\
\hline U.S. gallons _- & (ga & 3.785 & Litres & (l) \\
\hline eet $\ldots$ & (acre & 1,233 & Cubic $m$ & $\left(\mathrm{~m}^{3}\right)$ \\
\hline $\begin{array}{l}\text { Cubic feet } \\
\text { U.S. gallons }\end{array}$ & $\left(\mathrm{ft}^{3}\right)$ & 0.02832 & Cubic metres & $\left(\mathrm{m}^{3}\right)$ \\
\hline per minute & $(\mathrm{gal} / 1$ & 0.06309 & $\begin{array}{l}\text { Litres } \\
\quad \text { per second }\end{array}$ & $(\mathrm{l} / \mathrm{s})$ \\
\hline $\begin{array}{l}\text { Cubic feet } \\
\text { per second }\end{array}$ & $\left(\mathrm{ft}^{3} / \mathrm{s}\right)$ & 0.02832 & $\begin{array}{c}\text { Cubic metres } \\
\text { per second }\end{array}$ & $\left(\mathrm{m}^{3} / \mathrm{s}\right)$ \\
\hline $\begin{array}{l}\text { Million gallons } \\
\text { per day }\end{array}$ & $(\mathrm{Mgal} / \mathrm{d})$ & 3,785 & $\begin{array}{l}\text { Cubic metres } \\
\text { per day }\end{array}$ & $\left(\mathrm{m}^{3 / d}\right)$ \\
\hline $\begin{array}{l}\text { Cubic feet } \\
\text { per second per } \\
\text { square mile }\end{array}$ & $\left(\mathrm{ft}^{3} / \mathrm{s} / \mathrm{m}^{2}\right)$ & 0.0109 & $\begin{array}{c}\text { Cubic metres } \\
\text { per second } \\
\text { per square } \\
\text { kilometre }\end{array}$ & $\begin{array}{l}\left(\mathrm{m}^{3} / \mathrm{s} /\right. \\
\left.\mathrm{km}^{2}\right)\end{array}$ \\
\hline
\end{tabular}

Sophisticated tools are available to assist in the evaluation of alternative plans. The following section of the report considers some of the technology available and the data requirements for applying the technology.
TABLE 2.-Potential water-supply problem areas [Table after U.S. Dept. of the Interior, FWQA, 1970, Appendix H]

\begin{tabular}{|c|c|}
\hline Subbasin & Areas \\
\hline Mississippi headwaters & $\begin{array}{l}\text { Minneapolis-St. Paul metropolitan } \\
\text { area. }\end{array}$ \\
\hline Chippewa-Black & None. \\
\hline Wisconsin & Marshfield, Wis. \\
\hline Rock & None. \\
\hline Illinois & $\begin{array}{l}\text { Chicago suburbs, Decatur and } \\
\text { Springfield, Ill. }\end{array}$ \\
\hline Kaskaskia & None. \\
\hline Big Muddy & None. \\
\hline Meramec & None. \\
\hline Salt $\ldots \ldots \ldots$ & $\begin{array}{l}\text { Mexico, Paris, Vandalia, Centralia, } \\
\text { and Troy, Mo. }\end{array}$ \\
\hline Fox-Wyaconda-Fabius _._. & Kahoka and Palmyra, Mo. \\
\hline Des Moines & Worthington, Minn. \\
\hline Skunk & Ames, Iowa. \\
\hline Iowa-Cedar & $\begin{array}{l}\text { Austin and Albert Lea, Minnesota; } \\
\text { Forest City, Mason City, Water- } \\
\text { loo, and Cedar Rapids, Iowa. }\end{array}$ \\
\hline Turkey-Maquoketa-Upper & \\
\hline Iowa-Wapsipinicon & None. \\
\hline Cannon-Zumbro-Root & Rochester, Minn. \\
\hline Minnesota & $\begin{array}{l}\text { Marshall, New Ulm, Mankato, } \\
\text { and Fairmont, Minn. }\end{array}$ \\
\hline
\end{tabular}

\section{INTEGRATING GROUND WATER INTO WATER-RESOURCE PLANNING}

Advances in techniques in ground-water hydrology during recent years have provided methods that the hydrologist can use for planning and design of groundwater developments. Therefore, the manager can now resolve some of the development and management questions that historically have bred uncertainty when this part of the water resource was considered for development.

\section{TECHNOLOGY AVAILABLE FOR PLANNING}

An impressive array of tools is available for planning development of ground water and efficient conjunctive use of ground water and surface water. Models, in particular, have achieved greater utility as analytical tools in hydrology since computers have become available. A mathematical model of a ground-water basin or aquifer is designed to describe in mathematical language how the basin or aquifer functions under various conditions of development.

An advantage that a mathematical model has over a verbal description of a system is that the model describes the system in more concise, quantitative terms. Such a description facilitates considering a problem in its entirety and considering all interrelations simultaneously. For example, a mathematical model of a ground-water basin facilitates analysis of the mutual influence of the climatic, geologic, hydraulic, and manmade conditions that affect the basin.

A mathematical model of part of the multiple aquifer system in northeastern Illinois (Prickett and Lonnquist, 1971) is an example of a successful mathematical 
model in the Upper Mississippi Region. The purpose of the model was to improve on previous methods for predicting water-level declines in response to projected ground-water development. Also, Weeks and Stangland (1971) used a mathematical model to show the effects of irrigation on streamflow in a part of central Wisconsin.

Computer programs have been written that incorporate certain water-quality parameters into digital models. Though still in the early stages of development, these programs make it possible to describe changes in water quality that result from changes in watermanagement practices or to predict the fate of liquid contaminants released into the environment. Thus, a pilot project now underway in the Arkansas River valley of Colorado will attempt to describe and predict on a monthly basis changes in salinity in the alluvial aquifer and in the adjacent stream.

In the Upper Mississippi Region, excellent opportunities exist for the application of ground-waterquality modeling techniques in Minnesota and Wisconsin. For example in Minnesota, "the land of 10,000 lakes," real-estate development has resulted in many cases of lake-water degradation. Septic tanks, or other waste-disposal facilities, release nutrients to ground water in the vicinity of a lake. The nutrients migrate to the lake and degrade the quality of lake water. In many places little is known about the ground-water flow pattern near lakes or of the diffusion pattern and rate of movement of nutrients in the ground water. In order to set meaningful standards for waste-disposal facilities near lakes, such knowledge is essential. Model studies offer one method of gaining such an understanding.

The results of a model analysis are no more reliable than the data that are used to construct the model. The technical capability and experience of the hydrologist and his staff also markedly influence the accuracy of model calibration and of prediction analysis. Most model studies benefit from a team approach. The team may consist of a geologist, hydrologist, and geochemist, or other professionals. Some studies may require assistance of specialists, such as lawyers, economists, ecologists, and soil scientists.

Modeling is but one of the techniques that compose the systems engineering method. Hydrologists have successfully applied the systems method such that the literature is replete with useful applications of systems analysis to regional water-resource studies. The application of systems engineering to solving water-resource problems was in part pioneered by the Harvard Water Program staff (Maass and others, 1962). Although the Harvard group did not deal explicitly with ground water in their experimental systems, they stated that methods could be elaborated to account for ground water.

In summary, tools have been developed and are avail- able for use in planning the development of groundwater supplies, analyzing alternative conjunctive uses of ground water and surface water, and for evaluating management objectives within specified physical, economic, and social constraints. With the aid of these tools, ground water can be integrated into waterresource planning with a high degree of assurance and effectiveness.

\section{DATA REQUIREMENTS FOR PLANNING}

The data requirements for a planning study of a ground-water system depend upon the size and hydrologic complexity of the area and upon the type of water problems. Some planning studies need intensive investigation and large-scale model analyses, whereas others require only descriptive evaluation of the hydrologic data.

In determining the types of ground-water information to be presented in this report, it was assumed that water-resource planners in the Upper Mississippi Region will use systems engineering for establishing and implementing an optimal water-resource development scheme. What types of information are necessary for the application of the various methods that compose the systems method, including modeling and simulation?

The first type of information needed is that which helps the planner determine if the ground-water resource in the Upper Mississippi Region is available where needed or if it can be transported in sufficient quantity and acceptable quality at the right time. Regarding water quality, a study by the U.S. Department of the Interior, Geological Survey (1970a) summarizes ground-water-quality characteristics in the Upper Mississippi Region. A more detailed analysis of water quality is beyond the scope of this report.

The second type of information needed is estimates of the total resource available for allocation and of the individual demands among competing activities. Such estimates, along with cost estimates associated with allocation of the resource, are pertinent to the application of optimization techniques, such as linear programming. In the typical linear programming approach, available resources are allocated in an optimal manner among various competing activities.

This report provides an estimate of the total groundwater resource available. Initial estimates of water demand are available in the Upper Mississippi River comprehensive basin study (U.S. Army Corps of Engineers, 1970a, Appendices A-P). This report includes no estimates of costs for developing and delivering ground water because costs vary widely from place to place and from use to use. However, when specific requirements and a time frame are specified, cost estimates can be developed for a given locality. 
The third type of information needed is estimates of storage coefficients, transmissivities, aquifer boundaries, the degree of connection between streams and aquifers, and other relevant hydrologic parameters. Such information is basic to the application of system modeling and simulation.

Many pertinent data are already available; these are summarized in the following sections of this report.

\section{ASSESSING THE GROUND-WATER RESOURCE}

\section{GEOLOGIC FRAMEWORK}

Alluvium and outwush deposits (fig. 2) constitute the most productive part of the ground-water system in the Upper Mississippi Region. Streams draining the glaciated part of the igion have redeposited size-sorted glacial sediments beyond the southernmost encroachment of the glacial ice during the Ice Age and thus have helped to create permeable aquifers throughout the region. Subsequent references to the valley of the Mississippi River refer to the area adjacent to the main stem of the river that is underlain by outwash and alluvial deposits (fig. 2).

Holocene-age alluvium consisting of silt, sand, and gravel is present in the valley of the Mississippi River and adjacent to many of the larger streams. These deposits generally are finer grained and are less permeable than the outwash deposits. However, locally, they are excellent sources of water.

Outwash, which is composed predominantly of sand and gravel deposited by melt-water streams, is generally highly permeable and is an excellent source of water. Outwash deposits are most prevalent in Minnesota and Wisconsin, where they are generally in hydrologic connection with and not differentiated from the alluvial deposits.

Another highly productive part of the ground-water system is the buried sand and gravel deposits in the Mahomet bedrock valley of east-central Illinois (Visocky and Schicht, 1969). The buried valley and its major tributaries, though not shown in figure 2, underlie about 3,700 square miles in Illinois. Other buried valleys are present in various parts of the region.

Till is the principal glacial deposit in the region. It is a heterogeneous mixture of clay, silt, sand, and gravel; generally it has low transmissivity and, therefore, is generally a poor source of water. Moraines of unsorted till form low ridges along former fronts of glacial ice sheets. Glacial deposits are present in most of the region except for a part of Wisconsin and most of Missouri.

The Upper Mississippi Region is underlain by a series of bedrock units (fig. 3) that vary greatly in thickness and in hydrologic characteristics (U.S. Dept. of the Interior, Geological Survey, 1970b, p. 74-75). Depth to the bottom of the bedrock system, or basement, is greatest near the center of the Illinois basin (fig. 3). The basement crops out in the region in two centers of uplift-the Superior Upland and the Ozark Dome (fig. 3). Around these centers of uplift, rocks of younger age crop out in successive belts.

The slope on the basement complex is the central feature controlling the slope or dip of the younger bedrock units overlying the basement. The basement gently slopes toward the regional geosyncline of the Great Plains, west of the region, and slopes less gently toward the Michigan basin, the center of which is in the State of Michigan, and slopes toward the Illinois basin.

Three major bedrock aquifers are present in the Upper Mississippi Region. They are the Mount SimonHinckley of Precambrian and Cambrian age, the Cambrian-Ordovician, and the Silurian-Devonian aquifers. Locally, other names may be applied to these aquifers.

The Mount Simon-Hinckley aquifer is mostly sandstone. It is a source of water in southeastern Minnesota, western and southern Wisconsin, northern Illinois, and easternmost Iowa.

The Cambrian-Ordovician aquifer consists of several sandstone and dolomite formations which act as a hydraulic unit. The aquifer is a source of water in southeastern Minnesota, southern Wisconsin, northern Illinois, Iowa, northwestern Indiana, and much of eastern Missouri.

The Silurian-Devonian aquifer, which consists of several limestone and dolomite formations, supplies water to northeastern Iowa, northern Illinois, southeastern Wisconsin, and northwestern Indiana.

\section{PRECIPITATION-THE SOURCE}

Gross water input to the Upper Mississippi Region consists of the total regional precipitation. Groundwater inflow, if present, is insignificant relative to the total regional precipitation.

On the basis of average annual precipitation (fig. 4), estimated average precipitation rates in the various subbasins range from $5,000 \mathrm{M}$ gal/d (million gallons per day) in the Fox-Wyaconda-Fabius subbasin to $47,900 \mathrm{M}$ gal/day in the Illinois subbasin (table 3 ).

\section{EVAPOTRANSPIRATION-A MAJOR USE}

Evapotranspiration is the largest single component of natural fresh-water discharge from the hydrologic system. Average annual potential evapotranspiration, or the maximum rate at which water can be taken into the atmosphere, ranges from about 22 inches to about 32 inches (fig. 5).

The type of vegetation and the depth of vegetal root systems, in part, determine the depth limit of evapotranspiration. The lower limit of depth from which 


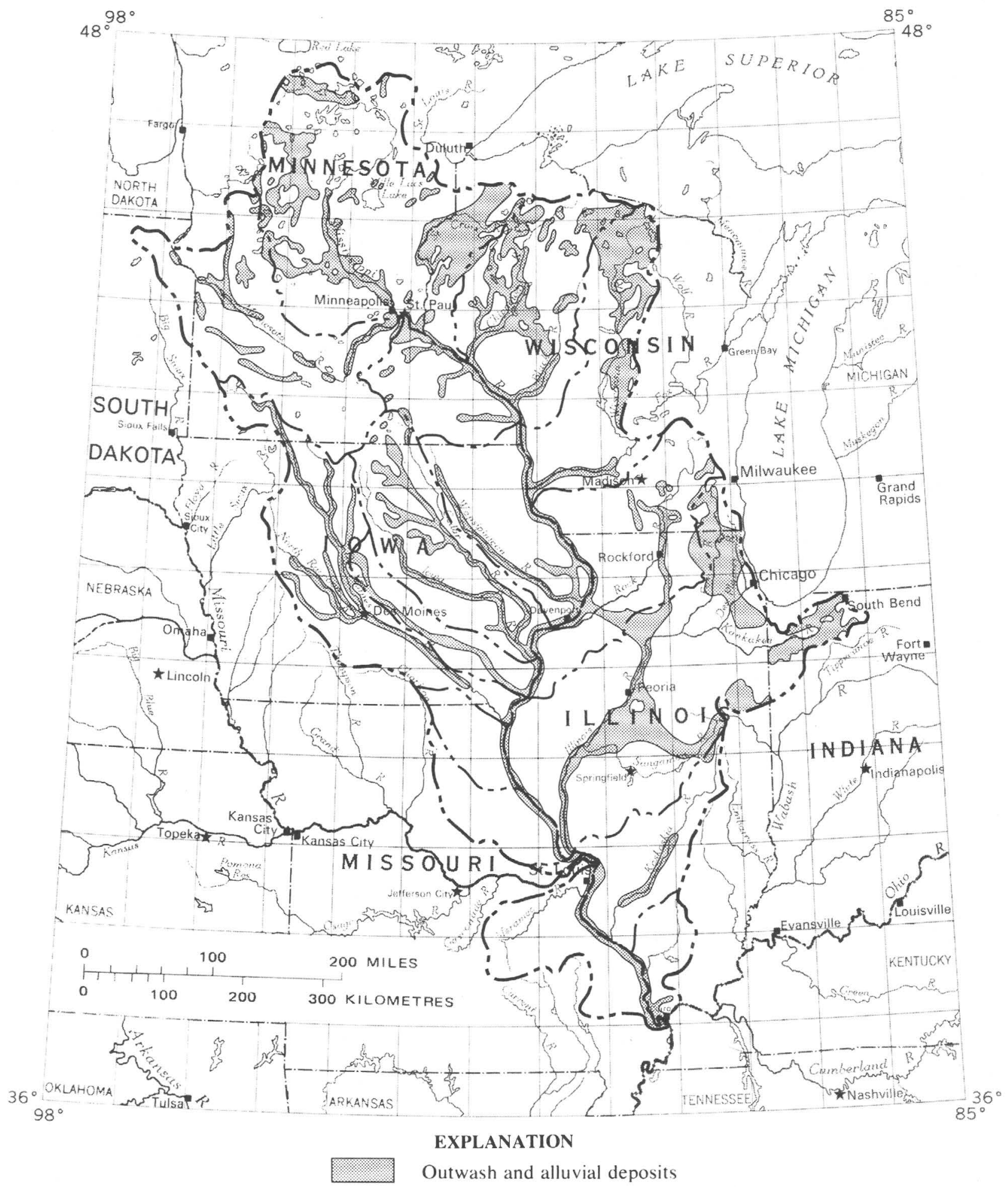

Figure 2.-Distribution of outwash and alluvial deposits.

evapotranspiration occurs is not accurately known, but it is generally not more than 15 feet.

Evapotranspiration is probably at a maximum from alluvial aquifers adjacent to gaining reaches of many streams where water is readily available to streamside vegetation. Ground water also evaporates and is transpired in wetlands and in the immediate vicinity of natural lakes fed by ground water. 


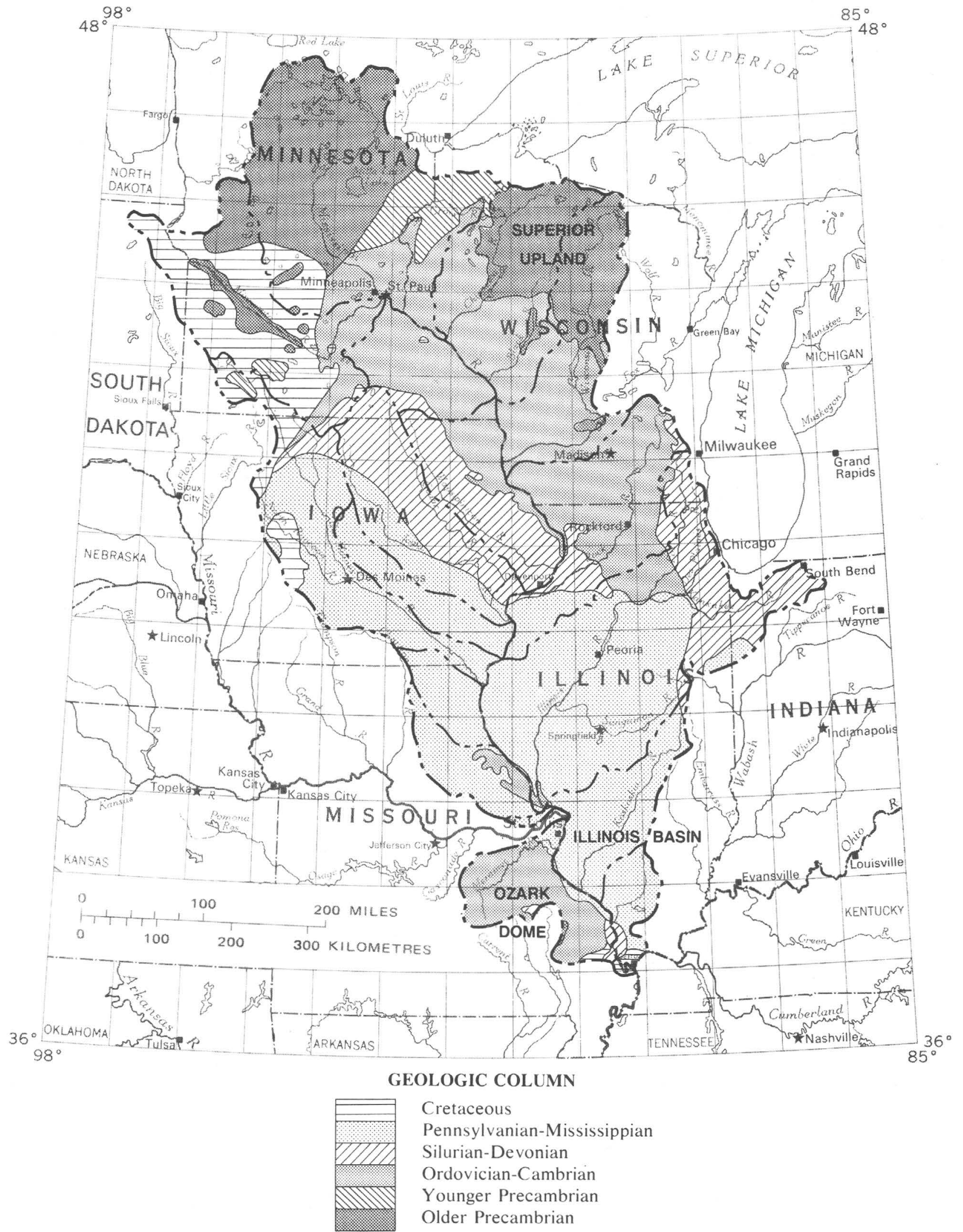

FIGURE 3.-Major geologic subdivisions of the bedrock in the Upper Mississippi Region. Adapted from U.S. Department of the Interior, Geological Survey (1970b). 


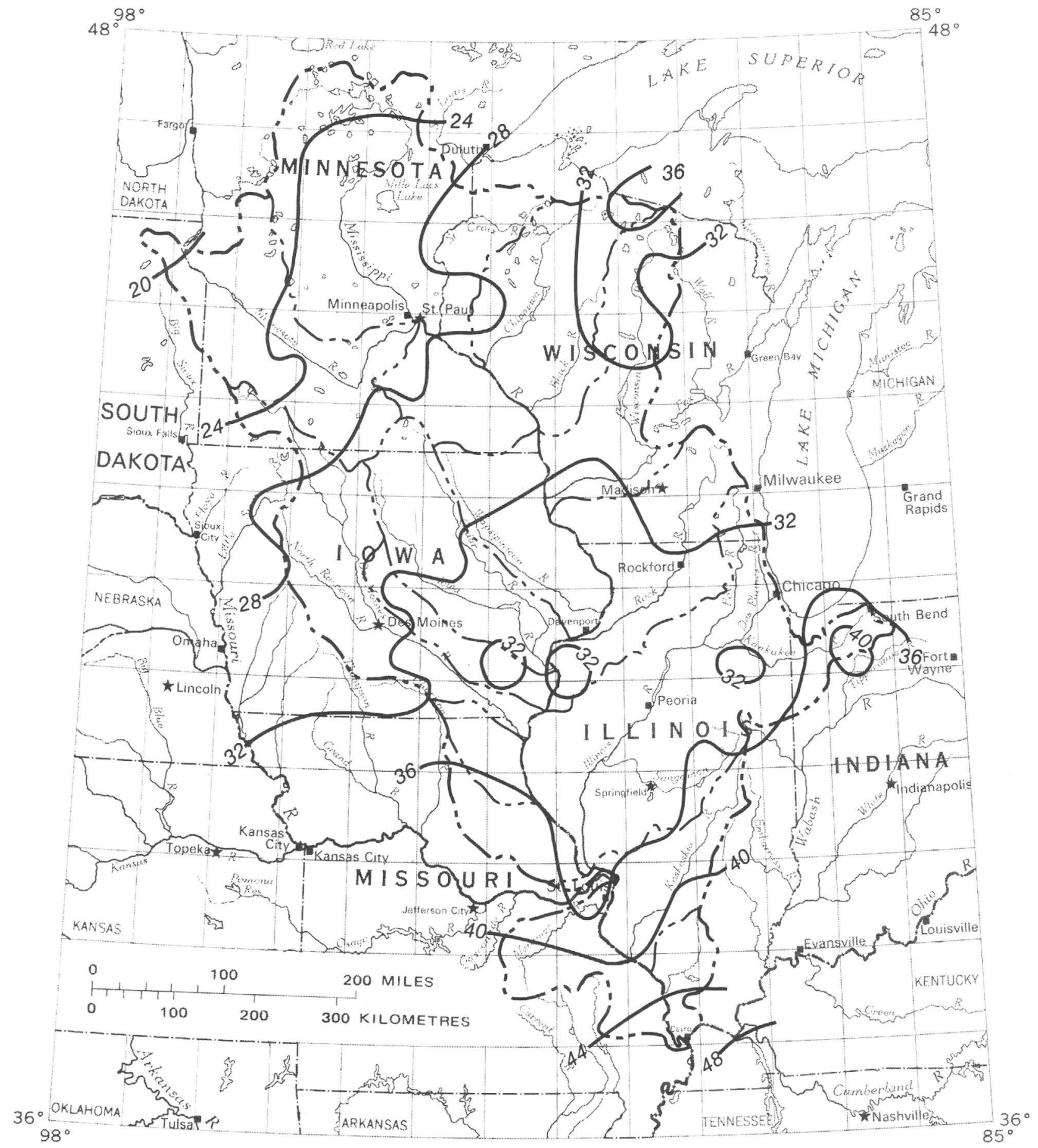

Figure 4.-Average annual precipitation, in inches. (Source is U.S. Dept. of Commerce, 1968.)

THE SUPPLY

Not all ground water in storage is available for development, but the following estimates of storage show the magnitude of water which, under specified conditions, can be considered available.
POT.ABLE WATER

For purposes of assessing the ground water in storage, potable water is defined as water containing less than $1,000 \mathrm{mg} / \mathrm{l}$ (milligrams per litre) dissolved solids. The definition is arbitrary because some water with less 
TABLE 3.-Estimated average annual subbasin precipitation

\begin{tabular}{|c|c|c|c|}
\hline Subbasin & $\begin{array}{l}\text { Estimated } \\
\text { annual } \\
\text { precipitation } \\
\text { (in/yr) }\end{array}$ & $\begin{array}{c}\text { Subbasin } \\
\text { area } \\
\left(\mathrm{mi}^{2}\right)\end{array}$ & $\begin{array}{l}\text { Estimated } \\
\text { precipitation } \\
\text { (M gal/d) }\end{array}$ \\
\hline Mississippi headwaters _ & 26.0 & 28,100 & 34,800 \\
\hline Chippewa-Black & 30.0 & 13,100 & 18,700 \\
\hline 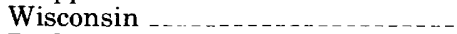 & 32.0 & 12,800 & 19,500 \\
\hline Rock & 33.0 & 14,500 & 22,800 \\
\hline Illinois & 34.0 & 29,600 & 47,900 \\
\hline Kaskaskia & 38.0 & 7,000 & 12,700 \\
\hline Big Muddy & 42.0 & 2,800 & 5,600 \\
\hline Meramec & 40.0 & 7,000 & 13,300 \\
\hline Salt $\ldots \ldots \ldots \ldots$ & 37.0 & 4,500 & 7,900 \\
\hline Fox-Wyaconda-Fabius & 35.0 & 3,000 & 5,000 \\
\hline Des Moines & 31.0 & 14,800 & 21,800 \\
\hline Skunk & 32.0 & 4,600 & 7,000 \\
\hline Iowa-Cedar & 32.0 & 12,800 & 19,500 \\
\hline \multicolumn{4}{|l|}{ Turkey-Maquoketa-Upper } \\
\hline Iowa-Wapsipinicon & 32.0 & 8,800 & 13,400 \\
\hline Cannon-Zumbro-Root & 29.0 & 5,700 & 7,900 \\
\hline Minnesota & 24.0 & 16,900 & 19,300 \\
\hline
\end{tabular}

${ }^{1} \mathrm{in} / \mathrm{yr}=$ inches per year.

than $1,000 \mathrm{mg} / \mathrm{l}$ dissolved solids is not potable. On the other hand, some municipal water-supply systems in the southwestern United States deliver water having dissolved solids exceeding $2,000 \mathrm{mg} / \mathrm{l}$. In this report, all water is considered a resource because most waters can be treated to remove undesirable constituents. Whether a given supply is potable or is usable only for other purposes is a planning or management decision.

Three categories of storage were specified for the purpose of computing the amount of potable ground water in storage in the region: (1) storage in the outwash and alluvial aquifer in the valley of the Mississippi River, (2) storage in the outwash and alluvial aquifers in the various subbasins, and (3) storage in all other aquifers.

The areal variance in available basic data on saturated aquifer thickness and aquifer characteristics make simplifying assumptions necessary in computing ground water in storage. For example, Illinois has excellent descriptive records of its water resources (Illinois Technical Advisory Committee on Water Resources, 1967, p. 9). Conversely, only sparse hydrogeologic data are available for the outwash and alluvial aquifer in the valley of the Mississippi River.

For calculating water in storage in the outwash and alluvial aquifer in the valley of the Mississippi River, the following assumptions were made: (1) all stored water is potable; (2) the aquifer is unconfined and has an average specific yield of 0.15 ; (3) above St. Paul, Minn., the average aquifer width is one-eighth mile, or 660 feet, the average saturated aquifer thickness is 30 feet, and the aquifer length is 500 miles; (4) below St. Paul the average aquifer width is 1 mile, the average saturated aquifer thickness is 75 feet, and the aquifer length is 850 miles; and (5) the product of the surface area of the aquifer, the saturated aquifer thickness, and the aquifer specific yield is the approximate volume of wa- ter in storage in the aquifer.

The assumptions are consistent with available data and probably yield conservative results. For example, the total thickness of outwash and alluvial deposits along the Mississippi River in Iowa is from 100 to 160 feet at most places (Steinhilber and Horick, 1970, p. 35). Also, the American Bottoms of the Mississippi River at East St. Louis, Ill., an area 30 miles long and as much as 11 miles wide consisting of outwash and alluvial deposits, averages 120 feet in thickness (Bergstrom and others, 1968, p. 160-161).

On the basis of the above assumptions, approximately 2,050 billion gallons of potable ground water is available from storage in the outwash and alluvial aquifer in the valley of the Mississippi River.

For calculating water in storage in the outwash and alluvial aquifers in the subbasins, the following assumptions were made: (1) all stored waier is potable, (2) the aquifers are unconfined, and (3) the specific yield of all aquifers is 0.15 . There are some locales where the assumptions may not hold, but, in general, available geohydrologic data suggest that they are reasonable.

The surface areas and saturated thicknesses of the outwash and alluvial aquifers were estimated from available geologic maps and geohydrologic data. The assumed saturated thicknesses are probably conservative estimates. Steinhilber and Horick $(1970$, p. 35) state that the thickness of alluvial deposits along the principal interior streams in Iowa ranges from 30 to 70 feet. In this report a saturated thickness of 30 feet was used for all outwash and alluvial aquifers in the State. Holt, Young, and Cartwright (1964, p. 193) state that the Wisconsin, Chippewa, and Rock River valleys contain as much as 200 feet of sand and gravel. In this report a saturated thickness of 50 feet was used for all outwash and alluvial aquifers in these subbasins. The assumed saturated thicknesses of the aquifers in the Rock, Illinois, Kaskaskia, and Big Muddy subbasins are probably conservative also (Illinois Technical Advisory Committee on Water Resources, 1967, figs. 29 and 30, p. 69 ).

On the basis of the above assumptions, approximately 43,000 billion gallons of potable water is in storage in the outwash and alluvial aquifers in the subbasins (table 4). The amount ranges from 300 billion gallons in the Big Muddy subbasin to 12,600 billion gallons in the Illinois subbasin.

Estimated total water in storage in the outwash and alluvial aquifers in the valley of the Mississippi River and the subbasins is 45,000 billion gallons. This volume is about twice that in storage in the outwash and alluvial aquifers of the Ohio River region (Bloyd, 1972, p. 46 ) or about 10 percent of the volume of water in storage in Lake Ontario. (See Bue, 1963, p. 11.) 


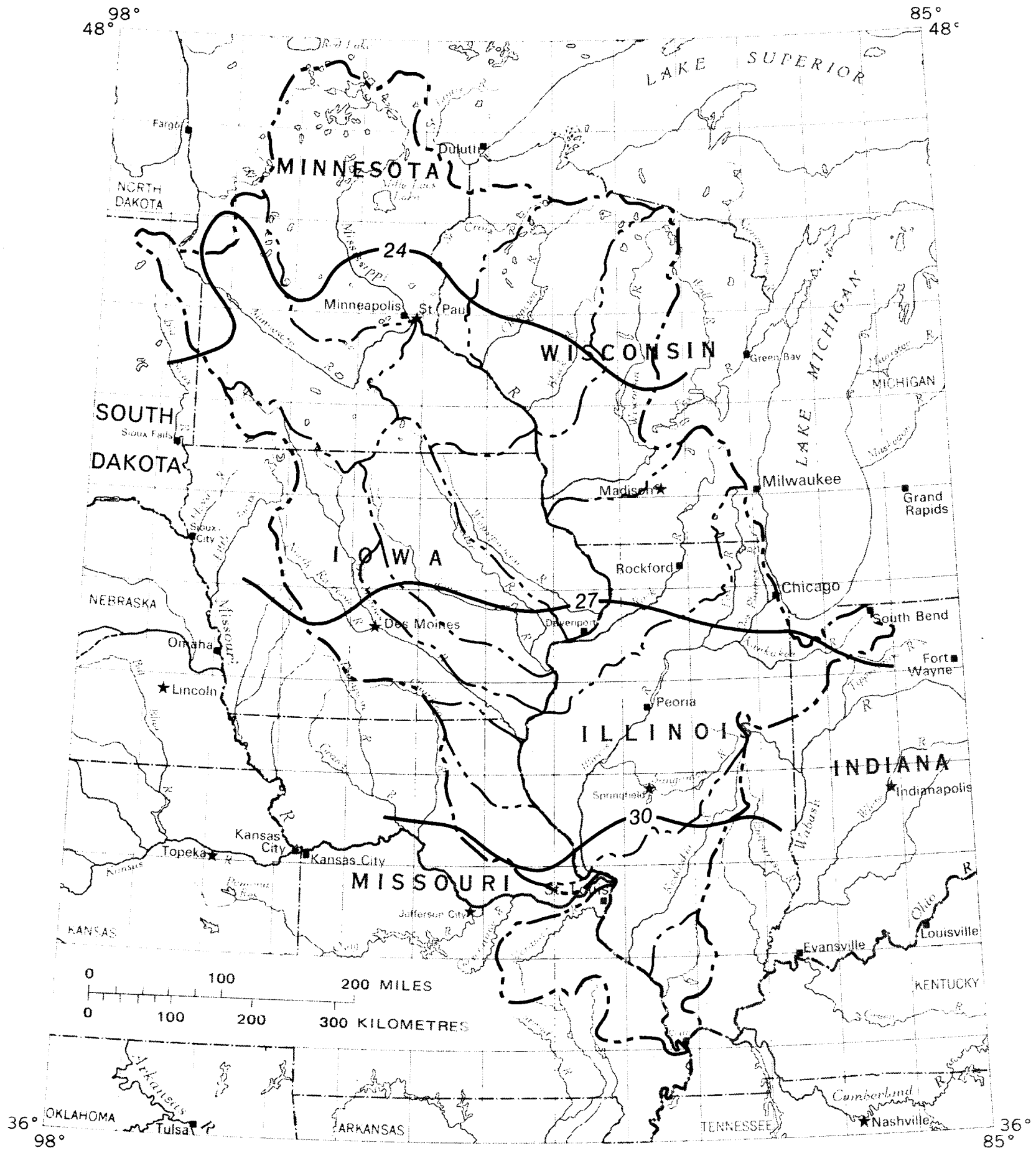

Figure 5.-Estimated average annual potential evapotranspiration, in inches. (Source is U.S. Army Corps of Engineers, 1970b.)

No attempt was made to calculate water in storage in the consolidated bedrock aquifers and the remaining unconsolidated surficial aquifers of the region. The sparse geohydrologic data make such a calculation unreliable. However, in the Ohio Region, where basic data are somewhat more abundant, potable water stored in the consolidated and minor unconsolidated aquifers is estimated to be four times that in the outwash and alluvial aquifers of the region (Bloyd, 1972). Possibly, such a ratio is applicable in the Upper Mississippi Region.

\section{SALINE WATER}

Saline ground water is most prevalent in the deep bedrock aquifers of central and southern Illinois and 
TABLE 4.-Calculation of water in storage in the outwash and alluvial aquifers of the subbasins

\begin{tabular}{|c|c|c|c|c|c|c|}
\hline \multirow{2}{*}{ Subbasin } & \multirow{2}{*}{$\begin{array}{c}\text { Assumed surface } \\
\text { area of outwash } \\
\text { and alluvium } \\
\left(\mathrm{mi}^{2}\right)\end{array}$} & \multirow{2}{*}{$\begin{array}{c}\text { Assumed } \\
\text { saturated } \\
\text { thickness } \\
\quad(\mathrm{ft})\end{array}$} & \multirow{2}{*}{$\begin{array}{c}\text { Saturated } \\
\text { volume } \\
\text { (billion } \\
\mathrm{ft}^{3} \text { ) }\end{array}$} & \multirow{2}{*}{$\begin{array}{l}\text { Assumed } \\
\text { specific } \\
\text { yield }\end{array}$} & \multicolumn{2}{|c|}{ Stored ground water } \\
\hline & & & & & $\underset{\mathrm{ft}^{3}}{\text { Billion }}$ & $\begin{array}{l}\text { Billion } \\
\text { gal }\end{array}$ \\
\hline Mississippi headwaters & 5,900 & 30 & 4,900 & 0.15 & 740 & 5,500 \\
\hline Chippewa-Black & 3,600 & 50 & 5,000 & .15 & 750 & 5,600 \\
\hline Wisconsin & 3,800 & 50 & 5,300 & .15 & 800 & 6,000 \\
\hline Rock & 1,400 & 50 & 2,000 & .15 & 300 & 2,200 \\
\hline Illinois & 8,000 & 50 & 11,200 & .15 & 1,680 & 12,600 \\
\hline - & 600 & 50 & 800 & .15 & 120 & 900 \\
\hline Big Muddy & 200 & 50 & 300 & .15 & 40 & 300 \\
\hline Meramec & ------ & ---- & $\ldots \ldots$ & ---- & $-\ldots .$. & ----- \\
\hline Salt & ---- & --- & ----- & ---- & ----- & $-\cdots-\cdots$ \\
\hline $\begin{array}{l}\text { Fox-Wyaconda-Fabius } \\
\text { Des Moines }\end{array}$ & 3,400 & --- & 2,800 & .15 & 420 & 3,100 \\
\hline Skunk & 900 & 30 & 800 & .15 & 120 & 900 \\
\hline Iowa-Cedar & 2,900 & 30 & 2,400 & .15 & 360 & 2,700 \\
\hline \multicolumn{7}{|l|}{ Turkey-Maquoketa-Upper } \\
\hline Iowa-Wapsipinicon & 1,100 & 30 & 900 & .15 & 140 & 1,000 \\
\hline Cannon-Zumbro-Root & 700 & 25 & 500 & .15 & 70 & 500 \\
\hline Minnesota & 1,900 & 30 & 1,600 & .15 & 240 & 1,800 \\
\hline Total & $\ldots . . . . .$. & ---- & -..... & $\ldots$ & 5,780 & 43,100 \\
\hline
\end{tabular}

western Iowa. The largest quantity of saline water is present in the Illinois basin (fig. 3). Here the basement rock is deeper than elsewhere in the Upper Mississippi Region. Assuming that the basement rock forms the bottom boundary of the saline zone, the bottom of the zone is about 9,000 feet below sea level. Sparse geohydrologic data negates the possibility of computing the amount of saline water in storage in the region.

\section{DEFINING MOVEMENT OF WATER THROUGH THE SYSTEM}

Except for the almost stagnant brine in the deeper zone of the Illinois basin, almost all ground water in the Upper Mississippi Region flows through the aquifers from place of intake or recharge to place of discharge. The rate of movement, under natural conditions, generally ranges from a few feet to a few hundreds of feet per year.

The recharge area of a consolidated or bedrock aquifer in the region is assumed to be the outcrop area of the aquifer; or if the aquifer is covered with glacial or alluvial deposits the recharge area is assumed to be the subcrop area underlying the glacial or alluvial deposits. The outcrop or subcrop area underlying perennial streams is generally a discharge area. On the basis of these factors, the recharge areas for all bedrock aquifers can be inferred from a detailed geologic map.

Once water enters a consolidated aquifer, there are two probable flow paths-the path through the intergranular or primary openings, called pores, and the path through secondary openings, such as rock fractures or solution channels. The intergranular openings were usually formed when the rocks were deposited as sediments. Although compaction and cementation generally occur with time and alter the original size and shape of the primary openings, some pore space generally remains available in rocks. Rock fracture and solution channels, which occur after original deposition, provide additional conduits for ground-water accumulation and movement. In consolidated rocks secondary openings generally transmit greater quantities of ground water at higher rates than primary openings.

The major discharge areas of the consolidated aquifers of the region are probably the Illinois basin (fig. 3) and the Mississippi River valley. Also Cambrian and Ordovician age aquifers probably discharge water into Lake Michigan (Weidman and Schultz, 1915, p. 78-81). In these discharge areas, vertical ground-water discharge or interaquifer flow is significant. Cartwright (1970, p. 917) used ground-water temperature anomalies in the Illinois basin to calculate the annual vertical ground-water discharge in an 1,800-squaremile area. He concluded that possibly as much as $\mathbf{9 5}$ percent of the discharge must be moving upward through vertical fractures or secondary openings.

Unconsolidated alluvial and outwash aquifers are recharged by infiltration of precipitation, upward interaquifer flow, and percolation of streamflow from losing streams. In most places the major source of recharge is precipitation. Under natural conditions, practically all exposed upland areas of unconsolidated aquifers are recharge areas.

The general direction of ground-water flow in the unconsolidated deposits is toward the streams. As suggested in the section "Stream-aquifer Interrelation," the streams are primary "sinks" for ground-water discharge. Interchange between surface-water and ground-water systems, however, is common. One reach of a stream may be gaining and another losing. Also, streams may gain or lose according to stage changes. 


\section{STREAM-AQUIFER INTERRELATION}

The purposes of this section of the report are: To demonstrate the general hydraulic connection between the shallow ground-water and surface-water systems, and to develop streamflow data needed in defining the ground-water resources.

Hydraulic connection between the shallow groundwater and surface-water systems is more evident in the Upper Mississippi Region than in many parts of the country. Thousands of natural ground-water fed lakes in Minnesota and Wisconsin are evidence of such hydraulic connection. The numerous perennial streams, which continue to flow even during drought, also testify to the connection between the two systems.

Hydraulic connection between the ground-water and surface-water systems and a vast supply of ground water indicate a potential for large economic benefits.

Because of the interchange between ground water and surface water, streamflow data for nonregulated perennial streams can be used to estimate ground-water discharge to streams, to estimate recharge as an approximate equivalent to discharge, and to estimate the hydraulic conductivity of aquifers that are in hydraulic connection with streams. Data from U.S. Geological Survey offices in the region were used for such purposes. Most of the data were obtained from studies of streamgaging networks made in each State by the Geological Survey. In these studies, a streamflow-frequency distribution was computed for each unregulated gaging site, where at least 10 years of streamflow record was available. Records for most sites were for more than the minimum 10-year period. The streamflow data used in this report were not adjusted to a common base period but were considered sufficiently accurate for the estimates sought.

Variation in streamflow can be depicted statistically with a cumulative frequency curve constructed on the basis of the amount of time during which stated values of streamflow are equaled or exceeded. The water in streams during periods of high flow is from both surface runoff and ground-water discharge. As streamflow decreases, the percentage of streamflow derived from surface runoff commonly decreases also. For most streams, below some reduced rate of flow almost all water in the channel is from ground water.

The flow equaled or exceeded 90 percent of the time, $:$ : the 90-percent flow, is generally assumed to be $\mathrm{al}^{\prime}$ ground-water discharge. Because the above assumption is based on empirical studies and because ground-water discharge varies seasonally, the use of other percentage flow values has been urged. Wyrick and Lloyd (1968, p. H19) mention data that indicate that the ground-water component of discharge to streamflow varies from the streamflow that is exceeded 60 percent of the time to that exceeded 90 percent of the time. Stuart, Schneider, and Crooks (1967, p. 42) concluded that for a stream in southeastern Pennsylvania, the flow exceeded more than about 75 percent of the time is all ground-water discharge.

The approach taken in this study is that two flowduration parameters define the annual ground-water discharge to streams better than one. This approach is based on the assumption that seasonal variation in base flow of a perennial stream is caused partly by seasonal variation in vapor discharge from aquifers. Because of the variation in vapor discharge, one parameter is necessary to define the ground-water discharge to streamflow during the season when vapor discharge is at a maximum, and another parameter is necessary for the season when vapor discharge is at a minimum.

Where ground water sustains streamflow in the Upper Mississippi Region, the water table in the vicinity of the streams is close to the land surface and is a ready source of moisture for plants; therefore, abundant vegetation generally grows along stream channels. Because vegetation on flood plains is situated between groundwater recharge areas and stream channels or groundwater discharge areas, the vegetation intercepts ground water enroute to discharge areas. During the summer, when transpiration is at a maximum, vegetation diverts more ground-water to the vapor phase than during the winter, when transpiration is at a minimum. This seasonal variation in magnitude of ground-water diversion by plants causes seasonal variation in base flow.

The assumption is made that the 90 -percent flowduration parameter is an indicator of base flow in a stream during that part of the year when ground-water vapor discharge is at a maximum and that the 60percent flow-duration parameter is an indicator during that part of the year when vapor discharge is at a minimum (fig. 6). For the purposes of this study, these choices seem reasonable.

Further discussion on the use of streamflow data to

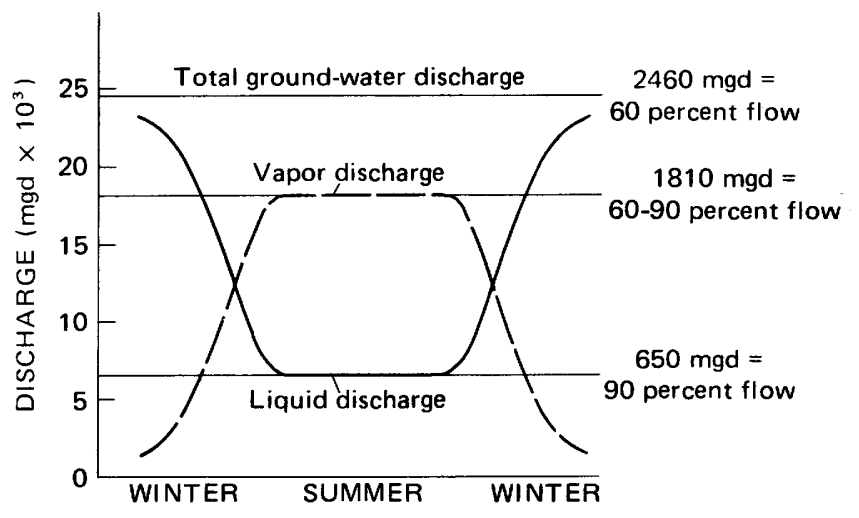

FigURE 6.-The liquid- and vapor-discharge components and their relation to total ground-water discharge. 
estimate ground-water recharge is presented in the section on "Ground-water Recharge."

The above approach of using two flow-duration parameters to define the annual ground-water discharge to streams is assumed applicable to the entire region even though the reason for the variation in base flow in the northern part of the region is complicated by frozen ground in winter that inhibits recharge and discharge from aquifers.

Where large reservoirs control flows, downstream flow records are not usable as indices of ground-water discharge. Also, water diverted from Lake Michigan is a major part of the annual flow of the Illinois River. For the Mississippi headwaters, Chippewa-Black, Wisconsin, Illinois, Des Moines, and Iowa-Cedar subbasins, the 60- and 90-percent flow duration parameters were determined by averaging values from nonregulated headwater and tributary flow records.

\section{GROUND-WATER RECHARGE}

Although various methods are used to determine "available" ground water or "safe yield" of a groundwater region, most methods assume that average annual ground-water recharge is the upper limit of ground water available.

The 60-percent flow-duration data were used to make order-of-magnitude estimates of subbasin groundwater recharge (table 5). Assuming that the 60-percent flows are indicators of natural ground-water discharge (fig. 6), they also can be used as indicators of natural ground-water recharge. This assumption implies that an approximate hydrologic equilibrium must exist between ground water entering and leaving the hydrologic system. Further discussion of this concept is presented in the section on "Principle of Continuity."

\section{PRODUCTIVITY OF AQUIFERS IN THE UPPER MISSISSIPPI REGION}

Estimates of the rates at which aquifers in the region can yield water to wells were made in the upper Mississippi River comprehensive basin study (U.S. Department of the Interior, Geol. Survey, 1970a, Appendix E). These estimates, which are modified slightly for this report, were made on the basis of rock type, geologic structure, known well and spring production, low-flow streamflow records, driller's records, and general knowledge of local geohydrology. For this report, only those areas having potential well yields greater than 500 $\mathrm{gal} / \mathrm{min}$ (gallons per minute) or less than $25 \mathrm{gal} / \mathrm{min}$ are illustrated (figs. 7 and 8).

\section{WATER-SUPPLY NEEDS}

The foregoing information in this report is presented in order to define the geohydrologic system and to assist evaluation of the potential of the ground-water supply in the Upper Mississippi Region; the next logical step is to consider water demand in the region.

\section{CURRENT}

Partial estimates of ground-water withdrawals are presented in the upper Mississippi River comprehensive basin study (U.S. Department of the Interior, Federal Water Quality Administration, 1970, Appendix H). Estimates are given for domestic and commercial ground-water use and for rural domestic and livestock use by subbasin for base year (1960) (U.S. Department of Agriculture, 1970, Appendix N). For this report, it was assumed that all 1960 rural water use was from ground-water sources. This assumption is probably not

TABLE 5.-Summary of ground-water recharge computations

\begin{tabular}{|c|c|c|c|c|c|}
\hline \multirow{2}{*}{ Subbasin } & \multirow{2}{*}{$\begin{array}{c}\text { Subbasin } \\
\text { area } \\
\left(\mathrm{mi}^{2}\right)\end{array}$} & \multirow{2}{*}{$\begin{array}{c}\text { 60-percent } \\
\text { flow } \\
{ }^{1}\left(\mathrm{ft}^{3} / \mathrm{s} / \mathrm{m}^{2}\right)\end{array}$} & \multicolumn{2}{|c|}{$\begin{array}{l}\text { Estimated } \\
\text { ground-water } \\
\text { recharge }\end{array}$} & \multirow{2}{*}{$\begin{array}{l}\text { Percent of } \\
\text { subbasin } \\
\text { precipitation }\end{array}$} \\
\hline & & & ${ }^{2}\left(\mathrm{ft}^{3} / \mathrm{s}\right)$ & $\mathrm{Mgal} / \mathrm{d}$ & \\
\hline Mississippi headwaters & 28,100 & 0.26 & 7,300 & 4,700 & 14 \\
\hline Chippewa-Black & 13,100 & .26 & 3,400 & 2,200 & 12 \\
\hline Wisconsin & 12,800 & .35 & 4,500 & 2,900 & 15 \\
\hline Rock & 14,500 & .32 & 4,650 & 3,000 & 13 \\
\hline Illinois & 29,600 & .15 & 4,450 & 2,900 & 6 \\
\hline Kaskaskia & 7,000 & .16 & 1,100 & 700 & 6 \\
\hline Big Muddy & 2,800 & .07 & 200 & 150 & 3 \\
\hline Meramec & 7,000 & .27 & 1,900 & 1,250 & 9 \\
\hline Salt & 4,500 & .05 & 250 & 150 & 2 \\
\hline Fox-Wyaconda-Fabius & 3,000 & .05 & 150 & 100 & 2 \\
\hline Des Moines & 14,800 & .07 & 1,050 & 700 & $\overline{3}$ \\
\hline Skunk & 4,600 & .14 & 650 & 400 & 6 \\
\hline Iowa-Cedar & 12,800 & .15 & 1,900 & 1,250 & 6 \\
\hline \multicolumn{6}{|l|}{ Turkey-Maquoketa-Upper } \\
\hline Iowa-Wapsipinicon & 8,800 & .25 & 2,200 & 1,400 & 10 \\
\hline Cannon-Zumbro-Root & 5,700 & .22 & 1,250 & 800 & 10 \\
\hline Minnesota & 16,900 & .05 & 850 & 550 & 3 \\
\hline Total - & & & & 23,150 & -... \\
\hline
\end{tabular}




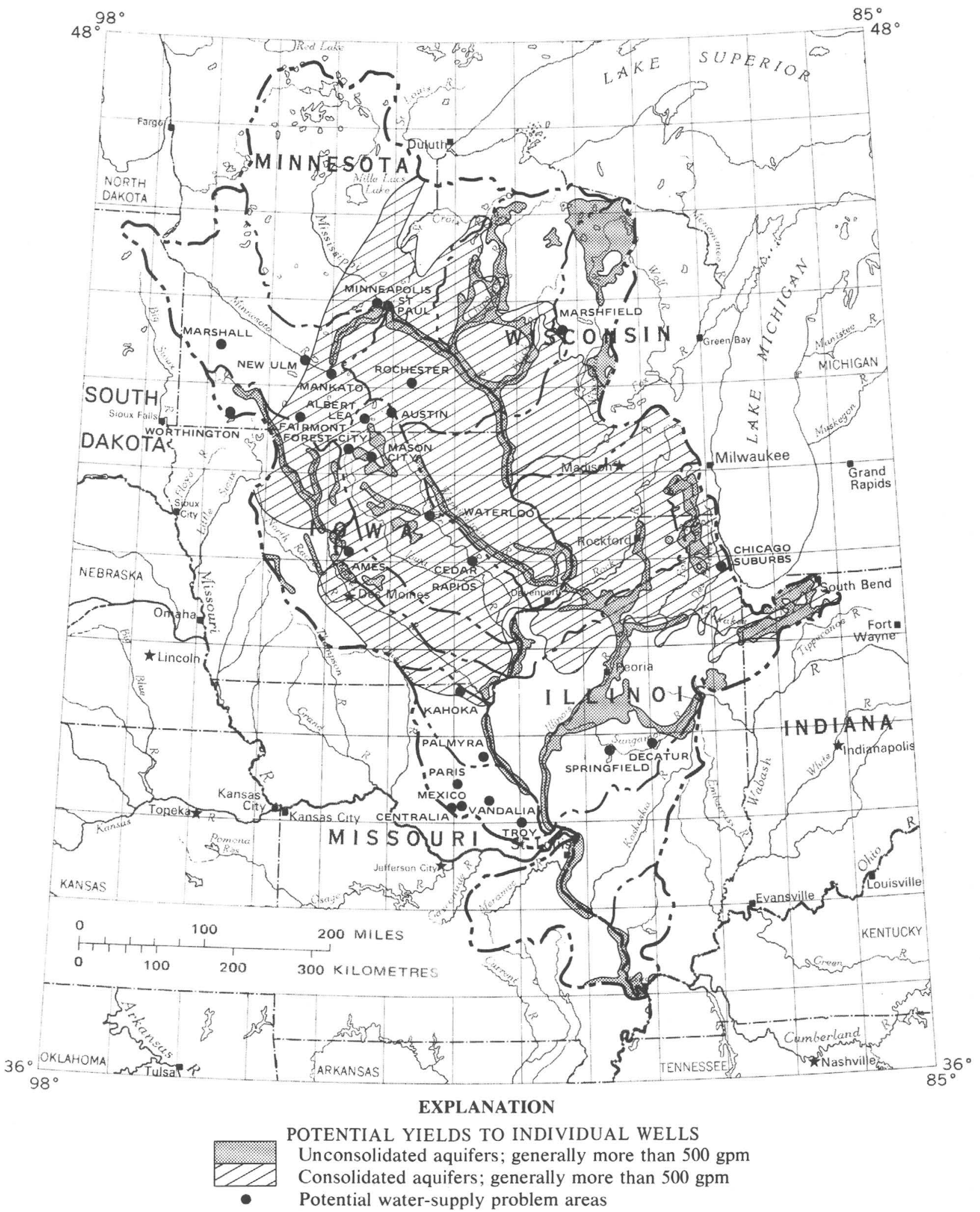

FIGURE 7.-High-yield sources of ground water. 


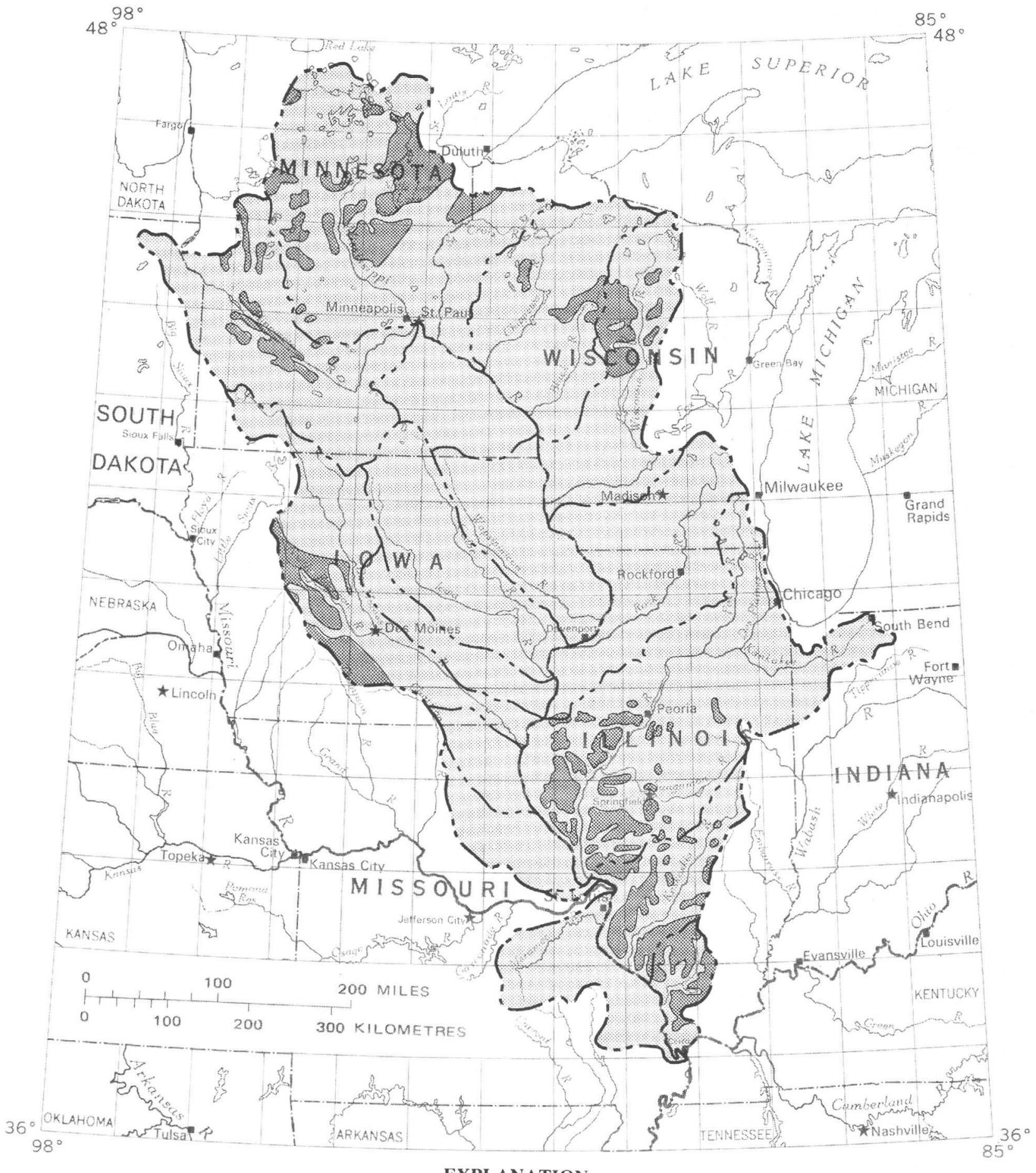

\section{EXPLANATION}

Areas where wells generally yield less than $25 \mathrm{gpm}$

Areas where wells generally yield more than $25 \mathrm{gpm}$

Figure 8.-Low-yield sources of ground water. 
TABLE 6.-Base year (1960) domestic, commercial, and rural groundwater use, Mgalld

\begin{tabular}{|c|c|c|c|}
\hline Subbasin & $\begin{array}{c}\text { Domestic } \\
\text { and commercial }\end{array}$ & $\begin{array}{l}\text { Rural domestic } \\
\text { and livestock }\end{array}$ & Total \\
\hline Mississippi headwaters & 56 & 41 & 97 \\
\hline Chippewa-Black & 11 & 22 & 33 \\
\hline Wisconsin $\ldots \ldots$ & 23 & 24 & 47 \\
\hline Rock & 83 & 30 & 113 \\
\hline Illinois & 154 & 75 & 229 \\
\hline Kaskaskia & 9 & 11 & 20 \\
\hline Big Muddy ... & .4 & 5 & 5 \\
\hline Meramec & 9 & 11 & 20 \\
\hline Salt & 2 & 11 & 13 \\
\hline Fox-Wyaconda-Fabius & .6 & 5 & 6 \\
\hline Des Moines & 23 & 48 & 71 \\
\hline Skunk & 8 & 16 & 24 \\
\hline Iowa-Cedar & 37 & 52 & 89 \\
\hline Turkey-Maquoketa-Upper & & & \\
\hline Iowa-Wapsipinicon & 15 & 36 & 51 \\
\hline Cannon-Zumbro-Root & 15 & 17 & 32 \\
\hline Minnesota & 16 & 35 & 51 \\
\hline Totals & 462 & 439 & 901 \\
\hline
\end{tabular}

Total basin industrial ground-water nse (1965) was $629 \mathrm{Mgal} / \mathrm{d}$ (Murray, 1968). Industrial ground-water use does not include water withdrawn for electric power cooling purposes.

much in error. Industrial ground-water use by subbasin was not presented in the above reports. However, Murray (1968) presents basinwide industrial ground-water use for 1965. Ground-water use data from the comprehensive study report and from Murray's report are presented in table 6 .

\section{PROJECTED}

Estimates of future subbasin water withdrawals, in addition to the base-year (1960) amounts, also are presented in the upper Mississippi River comprehensive basin study (U.S. Department of the Interior, Federal Water Quality Administration, 1970, Appendix H; U.S. Department of Agriculture, 1970, Appendix N). The estimated 2020 total water-use data were extracted from the reports and are presented in table 7 to permit further comparison and discussion.

\section{THE SIGNIFICANCE OF THE SUBSURFACE SYSTEM IN THE UPPER MISSISSIPPI REGION}

The foregoing information in the report suggests that the region's ground water is a large natural resource and that a demand for such a resource exists. The next logical step is to show how the ground-water resource may have a significant role in regional water development.

\section{THE POTENTIAL FOR ADDITIONAL DEVELOPMENT}

A comparison of ground-water withdrawals with estimated ground-water recharge (table 8 ) suggests that the ground-water resources of the Upper Mississippi Region are not being used at full potential. Annual domestic, commercial, and rural ground-water use
TABLE 7.-Estimated total municipal and industrial water use for the year 2020, (in Mgal/d)

\begin{tabular}{|c|c|}
\hline Subbasin & $\begin{array}{c}\text { Total water } \\
\text { use }\end{array}$ \\
\hline Mississippi headwaters & 1,050 \\
\hline Chippewa-Black & 220 \\
\hline Wisconsin $\ldots \ldots$ & 950 \\
\hline Rock & 1,200 \\
\hline Illinois & $-12,300$ \\
\hline Kaskaskia _... & 1,320 \\
\hline Big Muddy & 50 \\
\hline Meramec & 1,960 \\
\hline Salt & 90 \\
\hline Fox-Wyaconda-Fabius & 50 \\
\hline Des Moines & 660 \\
\hline Skunk & 140 \\
\hline Iowa-Cedar & 800 \\
\hline Turkey-Maquoketa-Upper & \\
\hline Iowa-Wapsipinicon & 620 \\
\hline Cannon-Zumbro-Root & 330 \\
\hline Minnesota & 330 \\
\hline Total & 22,070 \\
\hline
\end{tabular}

(1960) is about $900 \mathrm{Mgal} / \mathrm{d}$. Average annual regional ground-water recharge is about $23,000 \mathrm{Mgal} / \mathrm{d}$; therefore, base-year use is only 4 percent of recharge. Ground-water use (1965) by industry is only 3 percent of recharge.

The Des Moines subbasin is the only subbasin with base-year withdrawal rates greater than 10 percent of annual subbasin ground-water recharge rates. A similar comparison for the Mississippi headwaters and the Chippewa-Black and the Wisconsin subbasins suggests that present ground-water development for those subbasins is but a small part of the recharge, even if all the base-year industrial water use were from ground-water sources, which is not true.

TABLE 8.-Comparison of ground-water withdrawals with estimated ground-water recharge, in $\mathrm{Mgalld}$

\begin{tabular}{|c|c|c|}
\hline Subbasin & $\begin{array}{c}\text { Total }^{1} \\
\text { withdrawal }\end{array}$ & $\begin{array}{c}\text { Estimated } \\
\text { ground-water } \\
\text { recharge }\end{array}$ \\
\hline Mississippi headwaters & 97 & 4,700 \\
\hline Chippewa-Black & 33 & 2,200 \\
\hline Wisconsin & 47 & 2,900 \\
\hline Rock & 113 & 3,000 \\
\hline Illinois & 229 & 2,900 \\
\hline Kaskaskia - & 20 & 700 \\
\hline Big Muddy & 5 & 150 \\
\hline Meramec & 20 & 1,250 \\
\hline Salt & 13 & 150 \\
\hline Fox-Wyaconda-Fabius & 6 & 100 \\
\hline Des Moines & 71 & 700 \\
\hline Skunk & 24 & 400 \\
\hline Iowa-Cedar & 89 & 1,250 \\
\hline \multicolumn{3}{|l|}{ Turkey-Maquoketa-Upper } \\
\hline Iowa-Wapsipinicon & 51 & 1,400 \\
\hline Cannon-Zumbro-Root & 32 & 800 \\
\hline Minnesota & 51 & 550 \\
\hline Regionwide industrial use & 629 & 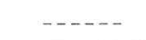 \\
\hline $\begin{array}{lll} & \end{array}$ & $-1,530$ & 23,150 \\
\hline
\end{tabular}

${ }^{1}$ Summation of base year (1960) domestic and commercial ground-water use, rural water use, and basinwide industrial ground-water use (1965). 


\section{GROUND WATER TO SATISFY LOCAL WATER REQUIREMENTS}

A well in almost any part of the region will yield enough water to satisfy domestic water requirements. The ubiquitous windmill of the past testifies to this fact.

Disregarding the chemical quality of water, water demands of many small municipalities or industries can be satisfied by wells in areas where wells yield more than $25 \mathrm{gal} / \mathrm{min}$. Also, ground water can be used to meet recreational demands, if a large surface reservoir is not required, for campsites, small off-stream fishing ponds, swimming pools, ice-skating rinks, or roadside rest stops.

In the Chicago suburban and Minneapolis-St. Paul metropolitan areas, large amounts of ground water are withdrawn locally. Total 1961 ground-water withdrawal in the Chicago area was $182 \mathrm{Mgal} / \mathrm{d}$ (U.S. Department of the Interior, Federal Water Quality Administration, 1970, Appendix H, p. H101). Groundwater withdrawal in the Minneapolis-St. Paul metropolitan area in 1960 was $136 \mathrm{Mgal} / \mathrm{d}$ (U.S. Department of the Interior, Federal Water Quality Administration, 1970, Appendix H, p. H41).

Rochester, Austin, and Albert Lea, Minn., three potential water-problem areas (table 2 and fig. 7), are underlain by the Prairie du Chien-Jordan aquifer, from which much water in the Minneapolis-St. Paul area is withdrawn. Detailed studies of this aquifer and of the Mount Simon-Hinkley aquifer would aid any future planning for water supplies for Rochester, Austin, and Albert Lea.

Ground water may partly satisfy future irrigation water requirements in the region. The potential for irrigation, and the water requirements for it have already been estimated (U.S. Department of Agriculture, 1970, Appendix N). Estimated water requirements range from 20,000 acre-feet per year $(50 \mathrm{Mgal} / \mathrm{d})$ in the Chippewa-Black subbasin to $1,756,000$ acre-feet per year (3,370 $\mathrm{Mgal} / \mathrm{d}$ ) in the Illinois subbasin (table 9); these estimates are based on the assumption that the irrigation period coincides with the freeze-free period. The growing seasons for the subbasins were estimated from published data (U.S. Department of Agriculture, 1970, Appendix N, p. N10).

Although all irrigation water requirements cannot be satisfied with ground water, the comparison of base year (1960) ground-water withdrawals with estimated ground-water recharge (table 7) suggests that ground water is available in substantial amounts for irrigation use.

Ground water is potentially valuable to the sportsfishery industry. For example, part or all of the water requirements for a fish hatchery may be satisfied with ground water. Also ground water may be used to aug-

\begin{tabular}{|c|c|c|c|}
\hline Subbasin & $\begin{array}{l}\text { Requirement } \\
\text { (1,000 acre-fect } \\
\text { per year) }\end{array}$ & $\begin{array}{l}\text { Growing } \\
\text { season } \\
\text { (days) }\end{array}$ & $\begin{array}{c}\text { Requirement } \\
(\mathrm{Mgal} / \mathrm{d})\end{array}$ \\
\hline Mississippi headwaters & 255 & 120 & 690 \\
\hline Chippewa-Black & 20 & 120 & 50 \\
\hline Wisconsin & 74 & 120 & 200 \\
\hline Rock & 745 & 165 & 1,470 \\
\hline Illinois & 1,756 & 170 & 3,370 \\
\hline Kaskaskia & 318 & 190 & 550 \\
\hline Big Muddy & 132 & 190 & 230 \\
\hline Meramec & 248 & 190 & 430 \\
\hline Salt & 189 & 190 & 320 \\
\hline Fox-Wyaconda-Fabius & 84 & 180 & 150 \\
\hline Des Moines & 653 & 165 & 1,290 \\
\hline Skunk & 175 & 165 & 350 \\
\hline Iowa-Cedar & 537 & 150 & 1,170 \\
\hline \multicolumn{4}{|l|}{ Turkey-Maquoketa-Upper } \\
\hline Iowa-Wapsipinicon & 381 & 150 & 830 \\
\hline Cannon-Zumbro-Root & 217 & 150 & 470 \\
\hline Minnesota & 515 & 150 & 1,120 \\
\hline Total & & & 12,690 \\
\hline
\end{tabular}

ment critically low streamflows during peak fishing seasons. Such augmentation may be extremely profitable in prime fishing areas. In both examples, ground water can be utilized as a secondary source during periods when surface water is not available in sufficient quantity or acceptable quality. Ground water álso can be used as the primary water source for fish hatcheries at those places where surface water is in short supply and ground-water temperature is favorable for growing game fish.

R. P. Novitzki (written commun., 1972) demonstrated that two trout streams in Wisconsin could be improved by augmenting streamflow with ground water. In the two streams, temperature extremes were moderated, and dissolved-oxygen concentrations increased during the augmentation. A model was used to predict potential temperature improvement during critical times. Improvement in living space was indicated by increases in stream volume and stage. Flow was also increased through the study reaches of both streams.

\section{GROUND WATER AS A REGIONAL RESOURCE}

Specific criteria used in this report to classify the ground water as a regional resource are:

1. Unconsolidated aquifer(s) of significant areal extent and saturated thickness of at least 30 feet must be present.

2. The aquifer(s) must be capable of yielding greater than $500 \mathrm{gal} / \mathrm{min}$ to individual wells.

3. Surface water must be available for artificial recharge of the aquifer(s).

The ensuing discussion assumes that necessary legislation and land acquisition are possible if development of ground water is feasible. Also all water referred to is assumed to be potable. 
The above criteria for classifying ground water as a regional resource are satisfied in the outwash and alluvial aquifer along much of the main stem of the Mississippi River in and south of St. Paul, and in the outwash and alluvial aquifers of the Illinois, the Lower Minnesota, the Wisconsin, the Lower Black, the Wapsipinicon, the Lower Rock, and the Upper Des Moines Rivers. Essentially these areas are underlain by outwash and alluvial aquifers with the potential to yield greater than $500 \mathrm{gal} / \mathrm{min}$ to individual wells (fig. 7). In these areas ground-water resources are of sufficient magnitude to satisfy more than just local needs.

The water in some of the bedrock aquifers, such as that in the Prairie du Chien-Jordan aquifer, could be considered a regional resource. A large supply is present and is available. Because only scant data are available on the location and extent of recharge to the aquifer, more detailed geohydrologic studies seem warranted.

In the above-mentioned areas where ground water can be considered a regional resource, the water requirements for a large population increase or other major water demands can be satisfied with ground water. For example, to show the approximate magnitude of a population increase that could be adequately supplied, the following assumptions are made:

1. Half of the excess of annual ground-water recharge over base-year (1960) ground-water use can be used to satisfy a particular water demand.

2. Half of the base-year industrial water use is from ground-water sources.

3. Water withdrawn is used only once.

4. Per capita water use is $150 \mathrm{gal} / \mathrm{d}$ (gallons per day), therefore, a 1-Mgal/d supply will satisfy the water requirements of approximately 6,500 people.

On the basis of the above assumptions, ground water is available for about 9 million additional people in the Wisconsin subbasin, 6 million in the Illinois subbasin, 2 million in the Des Moines subbasin, $1 \frac{112}{2}$ million in the Minnesota subbasin, and 1 million in both the Wapsipinicon and Black River drainage areas.

The above calculations for "increased population" are made only as an example of the opportunities that ground-water development presents. Note that artificial recharge of aquifers was not considered nor were the effects of development upon streamflow evaluated. Factors other than water supply, of course, will constrain development in the region.

In order to make maximum use of the available ground-water resources without excessive transportation costs, the maximum population density should be in the areas where ground water is considered a regional resource. There is a high population density pat- tern in the upper Illinois River subbasin but not in the other subbasins. The upper Des Moines subbasin is a farming area. Only 4 percent of the total land area of the subbasin was urbanized or built up in 1958 (U.S. Department of Agriculture, 1970, Appendix N, p. N37). The land-use pattern is similar in the Wisconsin subbasin and in the lower Black River and Wapsipinicon drainage areas.

The potential for additional industrial development also is enhanced in areas where ground water is classified as a regional resource. Almost any type of industry can satisfy their water requirements in these areas through the use of ground water.

\section{THE POTENTIAL FOR UNDERGROUND WASTE DISPOSAL}

Underground space in the Upper Mississippi Region can be considered a regional resource in the sense that it could be included in regional water-pollution control or waste-disposal plans. A simple definition of natural underground space might be interconnected pore or fracture space into which a fluid can be emplaced. Underground space is not necessarily vacant. In this section of the report emphasis is upon underground space occupied by saline water. Before assessing the potential for underground waste storage in the region, a discussion is presented on the characteristics generally considered necessary for successful waste injection and underground storage.

Two geologic characteristics generally considered necessary for the use of waste-injection wells are: (1) An injection zone with sufficient permeability, porosity, thickness, and areal extent to serve as a liquid-storage reservoir at safe injection pressures, and (2) an injection zone that is below the level of fresh-water circulation and is confined above by rocks that are, for practical purposes, impermeable to waste liquids.

Three characteristics indicate that an area has potential for waste injection and underground storage. These characteristics are: Aquifers containing water having more than $1,000 \mathrm{mg} / \mathrm{l}$ dissolved solids are available, the sedimentary rock sequence is 1,500 feet thick below the minimum depth of ground water containing more than $1,000 \mathrm{mg} / \mathrm{l}$ dissolved solids, and subsurface hydrology can be predicted because of relatively simple geologic structure. These characteristics are the converse of three listed by Warner (1969, p. B-28-A), which indicate an area has little feasibility for waste injection and underground storage.

On the basis of the above characteristics, especially the requirement for aquifers containing water having more than $1,000 \mathrm{mg} / \mathrm{l}$ dissolved solids, there seems to be only slight potential for underground storage of waste in the Upper Mississippi Region. As stated in the section on "Saline Water," saline ground water is most preva- 
lent in the deep aquifers of central and southern Illinois. These may be the areas with a potential for underground waste storage.

Further discussion of waste management is beyond the scope of this report. However, the technical aspects of the use of salaquifers for waste storage is now under study by the U.S. Geological Survey.

\section{WATER-MANAGEMENT IMPLICATIONS OF THE HYDROLOGIC ANALYSIS}

The effects of man's activities on the hydrologic system is a prime consideration in future planning. Basic to such consideration are an understanding of how the hydrologic system reacts to stresses and a knowledge of management alternatives. The purpose of this section is to discuss some basic hydrologic concepts and their relation to management and some specific watermanagement alternatives.

\section{SOME CONCEPTS RELATED TO WATER MANAGEMENT}

\section{PRINCIPLE OF CONTINUITY}

As a consequence of the principle of continuity, the quantities of water entering or leaving an arbitrary volume, such as the geohydrologic system of the Upper Mississippi Region, within a given time, are related by the hydrologic equation:

$$
\text { Inflow }=\text { outflow } \pm \text { Change in storage. }
$$

If the change in storage is positive, denoting an increase in storage, the change is added to the right side of the equation; if the change is negative, denoting a decrease in storage, the change is subtracted.

The hydrologic system of the Upper Mississippi Region will respond to any water-management program in a way that is consistent with the hydrologic equation. If ground water is used so that freshwater storage is not continually decreased, according to the hydrologic equation, ground-water inflow (recharge) and outflow (discharge) will be in balance. That is, increased consumptive use of ground water would have to be balanced by increased inflow (such as artificial recharge) or by a reduction of natural outflow (such as ground-water discharge to streams) to avoid a continual decrease in storage.

If inflow is less than outflow, fresh ground water in storage will be depleted. In Bellwood, Ill., a western suburb of Chicago, water levels in wells tapping bedrock aquifers declined 9 feet per year from 1913 to 1929 (Illinois Technical Advisory Committee on Water Resources, 1967, p. 107). By 1951 the water level had declined 495 feet, 305 feet since 1925, or 11.7 feet per year. By the mid-1960's the water level in the aquifer in the Bellwood area was 510 feet below the ground surface. If water withdrawal continues at the mid- 1960 rate, the level is expected to decline another 300 feet by 1980 , to about 810 feet below ground surface (Illinois Technical Advisory Committee on Water Resources, 1967, p. 108).

Such an overdraft of water in storage is not necessarily adverse. If temporary overdraft is part of a management program, management alternatives are increased and economic gains are possible.

\section{YIELD OF THE SYSTEM}

Discussions of development of the water resources of a region often focus on the "yield" or "safe yield" of the ground-water system. Todd $(1959$, p. 200$)$ defines safe yield as the amount of water that can be withdrawn annually without producing any undesired result.

Safe yield is useful in evaluating alternatives in managing a hydrologic system (Franke and McClymonds, 1972, p. F52). In practice, however, the concept has been misused-usually because a single value of safe yield is adopted and comes to be regarded as an inflexible natural law.

Often discussions focus on "available ground water," which can be defined as the amount of ground water that can be withdrawn on an areal basis for a long time, with conditions and limitations stated. As with safe yield, there is no one realistic value for available ground water. Depending upon conditions stated, available water can be defined and is useful. However, if conditions change, available water changes.

\section{CONSERVATION OF GROUND WATER}

Conservation can be defined as preservation, protection, or wise use of a resource-especially its planned management to prevent its irreversible depletion or deterioration. A diversity of opinion exists regarding exploitation of water resources and what is desirable or undesirable development and management. Various management alternatives are, thus, bound to arise. Planning involves evaluation of alternatives and choice of the most desirable or least undesirable alternative for action. Before discussing alternatives in the Upper Mississippi Region, the advantages (for management) of the subsurface system are discussed. These advantages are common to all management alternatives.

\section{ADVANTAGES (FOR MANAGEMENT) OF THE SUBSURFACE SYSTEM}

Realizing the f tential for further ground-water development in the region, the planner considers several advantages of using the subsurface system. A discussion of some of these advantages follows. 
A major advantage is the versatility of the subsurface system. Uses of the subsurface system are diverse. Broadly speaking, however, uses may be grouped into two categories: Storage of gases and fluids-principally natural gas and fresh water-for withdrawal, and injection of waste fluids for which withdrawal is not contemplated. These uses are likely to compete in many parts of the Upper Mississippi Region; hence, proper planning and resource utilization are warranted.

Another advantage is that ground water is generally renewable in the Upper Mississippi Region. In the section on "Ground-water Recharge," average annual ground-water recharge is estimated. In addition to natural recharge, aquifers may be recharged artificially. Recharge can be induced from streams if an aquifer and stream are hydraulically connected. Surfacespreading basins may be constructed adjacent to a stream in order to increase the infiltration area. Recharge wells may be used where hydraulic connection is poor or where land values are prohibitive. The choice of the type of a recharge facility is flexible. Depending on the site available, wells, reservoirs, ponds, lagoons, ditches, or pits may be utilized for recharge.

A successful surface-spreading facility has been in operation in Peoria, Ill., for about 20 years. A large part of the water supply for the Peoria area is obtained from sand and gravel aquifers adjacent to the Illinois River. The supply is maintained by artificial recharge of the aquifer with Illinois River water.

Records on the use of some recharge wells are conflicting, and both successes and failures have been reported. The injection of chlorinated water free from silt into a full well has yielded the best results. Chlorine helps prevent the growth of soil-clogging microorganisms; silt can clog well perforations or can even penetrate the aquifer, reducing its hydraulic conductivity; and introduction of air into an aquifer can also decrease the aquifer hydraulic conductivity. Metal casings can become encrusted where perforations are exposed to air or if the injected water is incompatible with the native water.

Another advantage associated with ground water is that in much of the region ground water is generally dependable throughout the year. Because the amount of ground water in storage is vast compared with annual pumpage, storage is not depleted significantly over a pumping year or even a series of years.

Another advantage is that ground water is widely distributed throughout the region. It is not equal everywhere in volume or rate of availability, but it is almost everywhere present in some quantity-in contrast to surface water, which is readily available only adjacent to perennial streams. An excellent reserve resource is, thus, available for emergency use during drought when surface-water resources are not available. Emergencies also could arise from contamination of surface-water resources or through natural catastrophies or war. Although ground water may not be the prime water resource in an area, a knowledge of its potential is necessary in planning for contingencies.

Ground water is generally not subject to large seasonal changes in temperature, which is of importance to some industrial water users. Seasonal temperature fluctuations are generally greatest at shallow depths and least in deeper parts of an aquifer.

Of further importance to many water users, ground water is generally uniform in chemical quality, and the quality is not subject to sudden or even seasonal changes. Because the volume of ground water in storage is large and because it moves slowly, replacement of water in storage is slow and, therefore, chemical quality and temperature do not fluctuate much over short time periods in most parts of the aquifer.

Another advantage is that the local environment is not severely altered when ground water is developed properly. Visible evidence of development is generally limited to a well, pump, pumphouse, and pipeline, most of which could be dismantled on cessation of pumping.

A major advantage is that the subsurface system is generally hydraulically connected with the surfacewater system. Where the connection is good, the combined system can be managed beneficially.

Beneficial management of a ground-water system involves lowering and raising of ground-water levels to regulate storage in response to time-varying requirements. Because a ground-water reservoir need not be maintained at full storage throughout the year, storage can be advantageously regulated.

The feasibility of a management plan depends partly on benefit compared with detriment caused by waterlevel changes. For simplification, ranges of water-level changes can be estimated for various pumpage rates. The ranges then can be divided into several increments. The probable effect on environment then can be estimated for each increment.

The feasibility of any management plan also depends upon the availability of answers to certain basic questions such as:

1. What is the areal extent, depth, and thickness of the ground-water reservoir?

2. Where are the hydrologic boundaries?

3. What is the amount of natural recharge and discharge?

4. Where are the areas of natural recharge and discharge?

5. At what rate can water be taken from or added to the reservoir?

6. Are there local geologic or hydrologic conditions 
that may hinder use of the reservoir?

7. What is the quality of water in storage and how may quality of water change because of reservoir management?

8. What is the probable life of the reservoir?

Many of these questions can be answered through this and other reports. More specific and definitive answers become possible when specific management plans are given.

A factor to be considered in a management plan is the rate at which the ground-water reservoir can be artificially recharged. Extraction rates are indicators of the maximum possible rates of artificial recharge. Theoretically, an aquifer can be recharged by injection wells at the same rate that water can be withdrawn under a given head differential. However, the tendency for wells and infiltration facilities to become clogged causes a decrease in recharge rate with time. Therefore, average recharge rate, with time, will probably be much less than design rate.

Sites with the best potential for management of storage are in and adjacent to flood plains of the major streams (fig. 2). These sites are underlain by thick and permeable aquifers fed by streams, which are ready sources of recharge.

With proper planning and resource use, the natural advantages of ground water commonly outweigh disadvantages, and, ideally, ground water receives full consideration in water planning.

\section{WATER MANAGEMENT ALTERNATIVES}

The following alternatives for developing the water resources of the Upper Mississippi River are classified according to the terms of the hydrologic equation that are most affected by the particular alternative. In all the alternatives, consideration is given to changes in fresh-water recharge and discharge, changes in ground-water storage, changes in the flow pattern within the aquifer, and changes in the quality of water.

\section{INCREASE INFLOW TO THE HYDROLOGIC SYSTEM}

Assuming that precipitation is the only natural source of fresh water in the Upper Mississippi Region, increased precipitation and the importing of water from other regions are the only methods of increasing the total amount of fresh water available. It may be possible to increase precipitation by cloud seeding. Cloud seeding would probably be most beneficial during the summer when water demands are at a maximum. Potential outside sources of potable water include the Great Lakes and, possibly, the water resources of the Wabash River subbasin in the Ohio Region. The legal, political, economic, and technical aspects of transport of imported water may be formidable and are beyond the scope of this report, but importing of water is, of course, feasible physically.

\section{SALVAGE OUTFLOW FROM THE HYDROLOGIC SYSTEM}

Reduction of ground-water evapotranspiration would yield additional quantities of water without an attendant significant change in storage. Suppression of evapotranspiration would be at the expense of vegetal growth where evapotranspiration is at a maximum. Such areas are adjacent to gaining reaches of many streams, in marshlands, and in the immediate vicinity of natural lakes fed by ground water. However, the likelihood of salvaging much of such water over long periods of time is probably remote. Accordingly salvage of evapotranspiration in the region does not seem to be a significant water-management alternative at present.

\section{USE OF ARTIFICIAL RECHARGE TO MAINTAIN BALANCE BETWEEN INFLOW AND OUTFLOW}

Although it is difficult to recharge the aquifers of the region artificially, such recharge could be considered in areas of significant ground-water development.

Theoretically, if, after use, water pumped from an aquifer is returned to it, yield would be almost limitless. In practice, each time water is recirculated the quality of the water deteriorates. However, tertiary treatment of waste water before recharge might alleviate to some degree the quality-deterioration problem.

If much pumpage is from deeper artesian aquifers and if water is recharged to shallow unconsolidated aquifers, a local imbalance will result in the deeper aquifers. Because vertical hydraulic conductivity is generally less than horizontal conductivity, water recharged to shallow aquifers will probably not move downward into the deeper aquifers as rapidly as it is pumped from them. After detailed geohydrologic studies are made of the high-yielding bedrock aquifers, such as the Prairie du Chien-Jordan aquifer, natural recharge areas can be determined, and artificial recharge could be attempted.

\section{SUMMARY}

The water-resource planner in the Upper Mississippi Region in many ways is in an enviable position. The region is rich in both surface water and ground water, therefore, increasing water demands are not cause for alarm. Planning does not have to focus on programs for solving drastic problems of water supply. Rather, the planner can act to conserve the present water resources. Further, the planner is fortunate in that sophisticated tools are available to assist in evaluating alternative plans.

This report emphasizes the role of ground water in the 
region. Total potable ground water in storage in the outwash and alluvial aquifers in the Mississippi River valley and the subbasins is about 45,000 billion gallons. This volume is about 10 percent of the water in Lake Ontario. Ground water in storage in other aquifers of the region is probably several times that in the outwash and alluvial aquifers. Estimated ground-water recharge in the subbasins is $23,000 \mathrm{M} \mathrm{gal} / \mathrm{d}$.

A comparison of ground-water withdrawals with estimated ground-water recharge suggests that ground water is not being used at full potential.

Ground-water use by domestic, commercial, and rural interests is only 4 percent of recharge. Ground-water use (1965) by industry is only 3 percent of recharge.

Part of the region has ground-water resources capable of satisfying more than local needs. Specifically, the water in the outwash and alluvial aquifers in much of the valley of the Mississippi River south of St. Paul, Minn., of the lllinois River, the lower Minnesota River, the upper Wisconsin River, the lower Black River, the Wapsipinicon River, the lower Rock River, and the upper Des Moines River can be considered a regional resource. Ground-water in the above areas could supply approximately 20 million additional people.

\section{SELECTED REFERENCES}

Bergstrom, R. E., and others, 1968, Ground-water resources of the Quaternary deposits of Illinois in the Quaternary of Illinois: Univ. of Ill. Coll. of Agriculture Spec. Puib. 14, p. 157-164.

Bloyd, R. M., Jr., 1972, Summary appraisals of the Nation's groundwater resources-Ohio Region: U.S. Geol. Survey open-file report, $136 \mathrm{p}$.

Bue, C. D., 1963, Principal lakes of the United States: U.S. Geol. Survey Circ. 476, 22 p.

Cartwright, Keros, 1970, Groundwater discharge in the Illinois basin as suggested by temperature anomalies: Water Resources Research, v. 6, no. 3, p. 912-918.

Franke, O. L., and McClymonds, N. E., 1972, Summary of the hydrologic situation on Long Island, New York, as a guide to water-management alternatives: U.S. Geol. Survey Prof. Paper $627-\mathrm{F}, 59 \mathrm{p}$.

Holt, C. L. R., Jr., Young, K. B., and Cartwright, W. H., 1964, The water resources of Wisconsin, in Blue Book: Univ. of Wis. Geol. and Nat. History Survey, p. 178-198.

Illinois Technical Advisory Committee on Water Resources, 1967, Water for Illinois, a plan for action: $452 \mathrm{p}$.

Maass, Arthur, and others, 1962, Design of water-resource systems: Cambridge, Mass., Harvard Univ. Press, 620 p.

Murray, C. R., 1968, Estimated use of water in the United States,
1965: U.S. Geol. Survey Circ. 556, 53 p.

Prickett, T. A., and Lonnquist, C. G., 1971, Selected digital computer techniques for ground-water resource evaluation: Urbana, Illinois Water Survey Bull. 55, 62 p.

Steinhilber, W. L., and Horick, P. J., 1970, Ground-water resources of Iowa, in Water resources of Iowa-a symposium: Iowa Acad. Sci., p. 29-49.

Stuart, W. T., Schneider, W. J., and Crooks, J. W., 1967, Swatara Creek basin of southeastern Pennsylvania, an evaluation of its hydrologic system: U.S. Geol. Survey Water-Supply Paper 1829, $79 \mathrm{p}$.

Todd, D. K., 1959, Ground-water hydrology: New York, John Wiley \& Sons, $336 \mathrm{p}$.

U.S. Army Corps of Engineers, 1970a, Upper Mississippi River comprehensive basin study, Washington, U.S. Govt. Printing Office. Volumes I-IX.

1970b, Climatology and meteorology: Appendix C to Upper Mississippi River Comprehensive Basin Study, v. III: Washington, U.S. Govt. Printing Office.

-1970c, Economic base study and projections: Appendix $P$ to Upper Mississippi River Comprehensive Basin Study, v. VIII: Washington, U.S. Govt. Printing Office.

U.S. Department of Agriculture, 1970, Agriculture: Appendix N to Upper Mississippi River Comprehensive Basin Study, v. VI: Washington, U.S. Govt. Printing Office.

U.S. Department of Commerce, Environmental Science Services Administration, 1968, Climatic atlas of the United States: Washington, U.S. Govt. Printing Office, 80 p.

U.S. Department of the Interior, Federal Water Quality Administration, 1970, Water supply and quality control, in Appendix $\mathrm{H}$ to Upper Mississippi River Comprehensive Basin Study, v. IV: Washington, U.S. Govt. Printing Office.

U.S. Department of the Interior, Geological Survey, 1970a, Ground water and geology, in Appendix E to Upper Mississippi River Comprehensive Basin Survey, v. III: Washington, U.S. Govt. Printing Office.

1970b, National Atlas of the United States of America: Washington, U.S. Govt. Printing Office, 417 p.

Visocky, A. P., and Schicht, R. J., 1969, Groundwater resources of the buried Mahomet bedrock valley: Urbana, Illinois Water Survey, Rept. Inv. 62, 52 p.

Warner, D. L., 1969, Administrative guidelines and evaluation criteria, in Ohio River Valley Water Sanitation Commission Perspective on the regulation of underground injection of wastewaters, Cincinnati, Ohio: Part 2, 65 p.

Weeks, E. P., and Stangland, H. G., 1971, Effects of irrigation on streamflow in the central sand plain of Wisconsin: U.S. Geol. Survey open-file report, $109 \mathrm{p}$.

Weidman, S., and Schultz, A. R., 1915, The underground and surface water supplies of Wisconsin: Wisconsin Geol. and Nat. History Survey, Bull. 35, Econ. Ser. 17, 664 p.

Wyrick, G. G., and Lloyd, O. B., 1968, Ground water resources: Appendix $\mathrm{H}$ to report for development of water resources in Appalachia, U.S. Army Corps of Engineers, 122 p. 

. 